Article

\title{
Influence of supports for selective production of 2,5-dimethylfuran via bimetallic copper-cobalt catalyzed 5-hydroxymethylfurfural hydrogenolysis
}

\author{
Sanjay Srivastava, G. C. Jadeja, Jigisha Parikh * \\ Department of Chemical Engineering, Sardar Vallabhbhai National Institute of Technology, Surat-395007, Gujarat, India
}

\section{A R T I C L E I N F O}

Article history:

Received 16 December 2016

Accepted 10 January 2017

Published 5 April 2017

\section{Keywords:}

5-Hydroxymethylfurfural

Hydrogenation

Hydrogenolysis

Copper-cobalt

Bimetallic

Biofuels

\begin{abstract}
A B S T R A C T
The hydrogenolysis of carbon-oxygen bonds is an important model reaction in upgrading biomass-derived furanic compounds to transportation fuels. One of these model reactions, namely conversion of 5-hydroxymethylfurfural (HMF) to the gasoline additive 2,5-dimethylfuran (DMF), is especially attractive. In this study, bimetallic $\mathrm{Cu}$-Co catalysts supported on $\mathrm{CeO}_{2}, \mathrm{ZrO}_{2}$, and $\mathrm{Al}_{2} \mathrm{O}_{3}$ were used for the selective hydrogenolysis of HMF to DMF. The structures of the fresh and used catalysts were studied using X-ray diffraction, the Brunauer-Emmett-Teller method, transmission electron microscopy, temperature-programmed reduction by $\mathrm{H}_{2}$, temperature-programmed desorption of $\mathrm{NH}_{3}$, and CHNS analysis. The structures were correlated with the catalytic activities. The $\mathrm{Cu}-\mathrm{Co} / \mathrm{CeO}_{2}$ catalyst produced mainly 2,5-bis(hydroxymethyl)furan via reduction of $\mathrm{C}=0$ bonds on large $\mathrm{Cu}$ particles. The $\mathrm{Cu}-\mathrm{Co} / \mathrm{Al}_{2} \mathrm{O}_{3}$ catalyst gave the best selectivity for DMF, as a result of a combination of highly dispersed $\mathrm{Cu}$, mixed copper-cobalt oxides, and suitable weak acidic sites. $\mathrm{Cu}-\mathrm{Co} / \mathrm{ZrO}_{2}$ had low selectivity for DMF and produced a combination of various over-hydrogenolysis products, including 2,5-dimethyltetrahydrofuran and 5,5-oxybis(methylene)bis(2-methylfuran), because of the presence of strong acidic sites. The reaction pathways and effects of various operating parameters, namely temperature, $\mathrm{H}_{2}$ pressure, and time, were studied to enable optimization of the selective conversion of $\mathrm{HMF}$ to $\mathrm{DMF}$ over the $\mathrm{Cu}-\mathrm{Co} / \mathrm{Al}_{2} \mathrm{O}_{3}$ catalyst.
\end{abstract}

(C) 2017, Dalian Institute of Chemical Physics, Chinese Academy of Sciences. Published by Elsevier B.V. All rights reserved.

\section{Introduction}

Energy crises, depletion of fossil fuel reserves, and global warming have increased interest in the production of biobased materials [1]. In confronting these challenges, biorefined materials have emerged as an alternative to industrial carbon. In biorefining, lignocellulosic biomass is transformed into value-added chemicals and fuels [2]. The hydrogenation/hydrogenolysis of furans such as furfural (FAL) and 5-hydroxymethylfurfural (HMF) has been widely studied for the production of biobased fuels such as 2-methylfuran (2-MF), 2-methyltetrahydrofuran, pentane, and 2,5-dimethylfuran (DMF) [3-6]. HMF is a valuable chemical because it can be converted to a variety of chemicals such as 2,5-bis(hydroxymethyl)furan (BHMF), 2-hydroxymethyl5-methylfuran (5-MFOL), DMF, and 2,5-dimethyltetrahydrofuran (DMTHF) (Scheme 1) [7-9]. DMF is an important compound because it has potential use in gasoline blends and can be converted to $p$-xylene through a Diels-Alder reaction with ethylene [10-12].

Precious metals, i.e. $\mathrm{Pt}, \mathrm{Pd}, \mathrm{Rh}, \mathrm{Ru}$, and $\mathrm{Au}$, are the main metals with potential uses in the hydrogenation of HMF to

\footnotetext{
*Corresponding author. Tel: +91-261-2251689; E-mail: jk_parikh@yahoo.co.in DOI: 10.1016/S1872-2067(17)62789-X | http://www.sciencedirect.com/science/journal/18722067 | Chin. J. Catal., Vol. 38, No. 4, April 2017
} 
DMF; Pd and Ru have been reported to give the best selectivities for DMF [9,13-17]. The first reported catalyst for hydrogenation of $\mathrm{HMF}$ to $\mathrm{DMF}$ was $\mathrm{CuRu} / \mathrm{C}$, which gave $71 \%$ yields of DMF from two different starting materials $[9,18]$. It was reported that the activity of this catalyst gradually decreased because of deactivation of active centres and/or the presence of chloride ions [9]. Thananatthanachon and Rauchfuss reported the conversion of HMF to DMF using Pd/C as a catalyst and formic acid as an additive [8]. An excellent yield, i.e. 93\%, with 99\% HMF conversion was achieved, but only when formic acid and $\mathrm{H}_{2} \mathrm{SO}_{4}$ were used. However, because of their highly corrosive nature and environmental concerns, the use of both formic acid and $\mathrm{H}_{2} \mathrm{SO}_{4}$ is restricted. Luijkx et al. [19] used a combination of $\mathrm{Pd} / \mathrm{C}$ and $\mathrm{HCl}$ to reduce HMF to DMF; The results were similar to those reported by Rauchfuss et al. [8]. $\mathrm{Zu}$ et al. [15] used $\mathrm{Ru} / \mathrm{Co}_{3} \mathrm{O}_{4}$ as a catalyst for the selective conversion of $\mathrm{HMF}$ to $\mathrm{DMF}$ at $130{ }^{\circ} \mathrm{C}$ and $0.7 \mathrm{MPa}$; they clearly identified the roles of $\mathrm{Ru}$ and $\mathrm{CoO}_{x}$, which are responsible for reduction and hydrogenolysis of carbonyl and hydroxyl groups, respectively.

Because of the high cost of noble metals, research on precious-metal-free catalysts which can effectively convert HMF to DMF is needed. Yang et al. [20] obtained a 76\% yield of DMF over $\mathrm{Ni} / \mathrm{Co}_{3} \mathrm{O}_{4}$ catalysts; the roles of $\mathrm{Ni}$ and $\mathrm{CoO}_{x}$ were similar to those reported for $\mathrm{Ru}$ and $\mathrm{CoO}_{x}$ by $\mathrm{Zu}$ et al. [15]. $\mathrm{Cu} / \mathrm{ZnO}$, $\mathrm{Cu}-\mathrm{Zn}$ alloy, $\mathrm{Cu} / \mathrm{MgO} / \mathrm{Al}_{2} \mathrm{O}_{3}$, $\mathrm{Ru}$-modified $\mathrm{Cu} / \mathrm{MgO} / \mathrm{Al}_{2} \mathrm{O}_{3}$, and $\mathrm{Cu}-\mathrm{PMO}$ catalysts have been examined in the hydrogenation of HMF to DHMF and DMF [21-23]. However, the development of low-cost and environmentally benign robust catalytic systems for this reaction is still in progress.

Recently, supported bimetallic Cu-Co nanoclusters have emerged as versatile catalytic systems for hydrogenation/hydrogenolysis reactions because of the presence of $\mathrm{Cu}(0), \mathrm{CoO}_{x}$ species, and mixed oxide phases [24-34]. It has been reported that early-transition-metal oxides such as $\mathrm{CoO}_{x}$, $\mathrm{ReO}_{x}$, and $\mathrm{MoO}_{x}$ can effectively split $\mathrm{C}-\mathrm{O}$ and $\mathrm{O}-\mathrm{H}$ bonds $[15,19,35,36]$. A combination of $\mathrm{Cu}$ metal and $\mathrm{CoO}_{x}$ could therefore be effective in the production of DMF by hydrogenation/hydrogenolysis of HMF. In our previous work, we hydrogenated FAL to 2-MF over bimetallic $\mathrm{Cu}$-Co catalysts supported on $\mathrm{SiO}_{2}, \mathrm{H}-\mathrm{ZSM}-5$, and $\mathrm{Al}_{2} \mathrm{O}_{3}$ [29]. $\mathrm{Cu}-\mathrm{Co} / \mathrm{Al}_{2} \mathrm{O}_{3}$ was the best hydrogenolysis catalyst because of the presence of small $\mathrm{Cu}$ particles and $\mathrm{Cu}-\mathrm{Cox}$ mixed phases, and synergies among $\mathrm{Cu}$, Co, and $\mathrm{Al}_{2} \mathrm{O}_{3}$.

The present work was undertaken based on the background described above. In this study, instead of using $\mathrm{SiO}_{2}$ and H-ZSM-5 as supports, materials which stabilize metal dispersion and improve oxygen storage (e.g. $\mathrm{CeO}_{2}$ and $\mathrm{ZrO}_{2}$ ) were examined and compared with $\mathrm{Al}_{2} \mathrm{O}_{3}$ as supports for $\mathrm{Cu}$-Co bimetallic catalysts. The structures of these synthesized catalysts were studied using X-ray diffraction (XRD), the Brunauer-Emmett-Teller (BET) method, transmission electron microscopy (TEM), temperature-programmed desorption of $\mathrm{NH}_{3}$ ( $\mathrm{NH}_{3}$-TPD), temperature-programmed reduction by $\mathrm{H}_{2}$ ( $\mathrm{H}_{2}$-TPR), and CHNS analysis. The activities and selectivities of these catalysts in the hydrogenolysis of HMF to DMF were investigated. $\mathrm{Cu}-\mathrm{Co} / \mathrm{Al}_{2} \mathrm{O}_{3}$ catalysts were best for the hydrogenolysis of biomass-derived HMF to DMF; DMF was selectively obtained in 78\% yield under mild conditions. The HMF conversion and DMF selectivity were optimized based on the reaction pathways and effects of the reaction parameters, namely temperature, $\mathrm{H}_{2}$ pressure, and time.

\section{Experimental}

\subsection{Materials}

Tetrahydrofuran (THF), HMF, and all the products shown in Scheme 1 (all GC grade) were purchased from Sigma-Aldrich, Mumbai, India. The supports, i.e. $\mathrm{CeO}_{2}, \mathrm{ZrO}_{2}$, and $\mathrm{Al}_{2} \mathrm{O}_{3}$ (purity 99\%), were purchased from Sterling Chemical Pvt., Ltd., Surat, India. Bimetallic $\mathrm{Cu}$-Co catalysts with $\mathrm{Cu}$ :Co molar ratios of 1,2 , and 4 were synthesized on $\mathrm{CeO}_{2}, \mathrm{ZrO}_{2}$, and $\mathrm{Al}_{2} \mathrm{O}_{3}$ at fixed $\mathrm{Cu}$

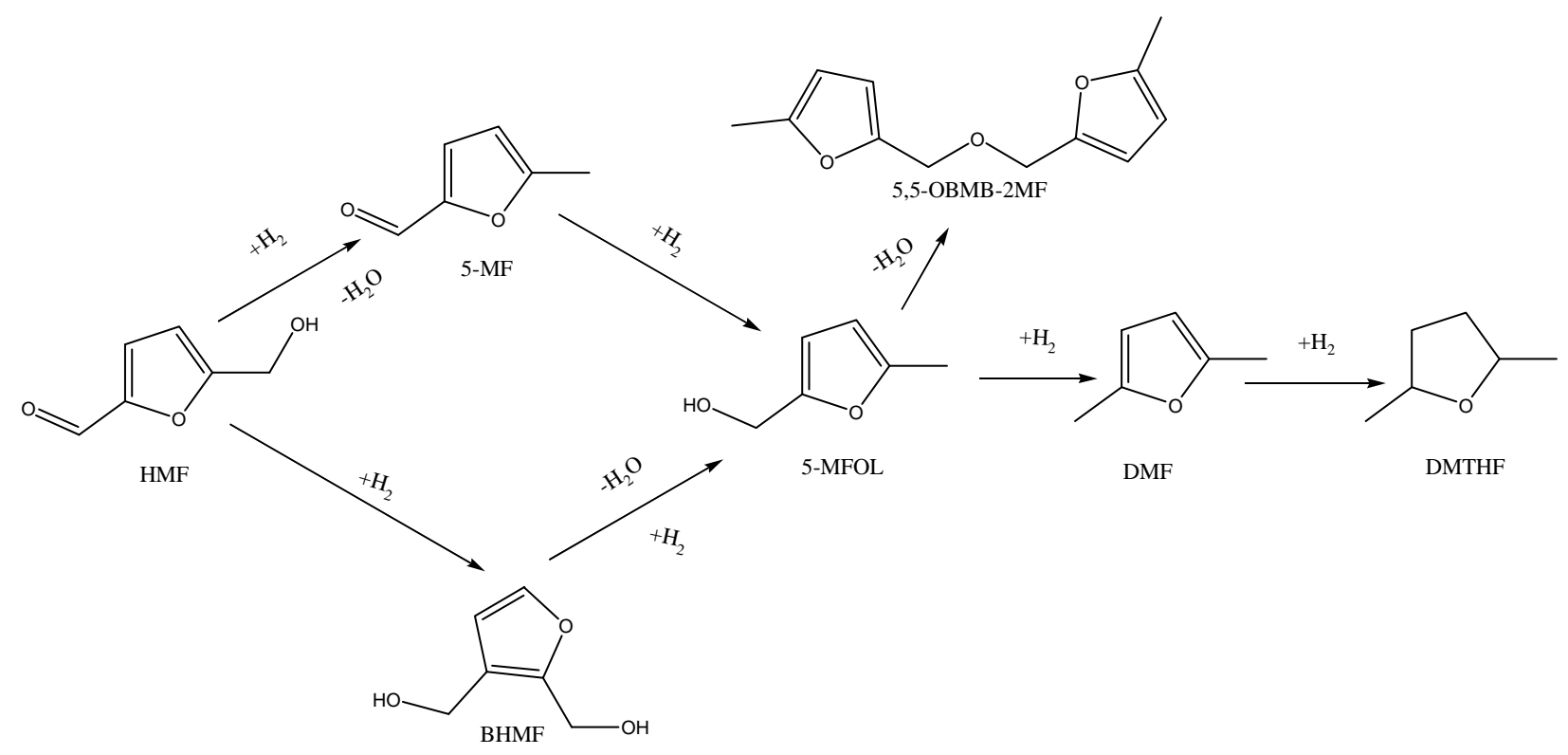

Scheme 1. Reaction pathway in DMF synthesis from HMF. 
loadings of $10 \mathrm{wt} \%$ by impregnation with aqueous solutions of $\mathrm{Co}\left(\mathrm{NO}_{3}\right)_{2} \cdot 6 \mathrm{H}_{2} \mathrm{O}$ and $\mathrm{Cu}\left(\mathrm{NO}_{3}\right)_{2} \cdot 6 \mathrm{H}_{2} \mathrm{O}$. Details of the synthesis and characterization of the supported bimetallic $\mathrm{Cu}$-Co catalysts are available elsewhere [29].

\subsection{Catalytic activity study}

Hydrogenation of HMF was performed in a 100-mL autoclave reactor (Amar Equipment Pvt., Ltd., Mumbai, India). Briefly, the catalyst $(0.5 \mathrm{~g})$ was reduced at $280 \pm 2{ }^{\circ} \mathrm{C}$ in a $\mathrm{H}_{2}$ flow at $1 \mathrm{MPa}$ for $3 \mathrm{~h}$. The reactor was cooled to room temperature and flushed with $\mathrm{N}_{2}$. The reactor was charged with HMF ( $2.5 \mathrm{mmol})$ in THF $(20 \mathrm{~mL})$. The catalytic activities of the prepared catalysts were investigated at $160-230{ }^{\circ} \mathrm{C}$ under a $\mathrm{H}_{2}$ pressure of $3.0 \mathrm{MPa}$ with stirring at $1000 \mathrm{r} / \mathrm{min}$. The reproducibility of each reaction was checked by repeating it twice. Product samples were analysed using a Sigma GC system with a flame ionization detector (FID). An AB-5 capillary column of dimensions $30 \mathrm{~m} \times 0.25 \mathrm{~mm} \times 0.5 \mu \mathrm{m}$ was used. In a typical procedure, the initial oven temperature was held at $50{ }^{\circ} \mathrm{C}$ for 2 min and increased to $300{ }^{\circ} \mathrm{C}$ at a ramping rate of $10{ }^{\circ} \mathrm{C} / \mathrm{min}$ and held for $2 \mathrm{~min}$. The product suspension $(1 \mu \mathrm{L})$ was injected into the capillary column using a 20:1 split ratio, with $\mathrm{N}_{2}$ as the carrier gas. The carbon balance was calculated in each run by measuring the carbon in the liquid phase using GC-FID; it was found to be $>92 \%$ in each run because of unidentified products. The unidentified products were quantified by subtracting the overall carbon balance at each step from $100 \%$. The following equation was used to determine the amount of carbon in the reaction mixture: carbon balance (\%) = moles of carbon after reaction (reactant and products)/moles of carbon before reaction (reactant) $\times 100$.

\section{Results and discussion}

\subsection{Catalyst structure}

\subsubsection{XRD results}

The effects of the support on the crystalline phases of the bimetallic $\mathrm{Cu}-\mathrm{Co}(\mathrm{Cu} / \mathrm{Co}=1)$ catalysts were investigated using XRD. The XRD patterns of the calcined and reduced catalysts are shown in Figs. 1-3. The XRD patterns of the $\mathrm{ZrO}_{2}$ and $\mathrm{CeO}_{2}$ catalysts show the presence of face-centred cubic (fcc) $\mathrm{ZrO}_{2}$ and (fcc) $\mathrm{CeO}_{2}$ crystalline structures (Fig. 1), based on the JCPDS files (JCPDS 83-0936 and JCPDS 81-0792) [37]. However, no (fcc) structure was observed for $\mathrm{Al}_{2} \mathrm{O}_{3}$; only a weak diffraction peak at $2 \theta=67^{\circ}$ indicated the presence of $\mathrm{Al}_{2} \mathrm{O}_{3}$. To gain further insights into the effects of the supports on active site formation in the bimetallic catalysts, we examined the XRD patterns of monometallic $\mathrm{Cu}(10 \mathrm{wt} \%)$ and $\mathrm{Co}(10 \mathrm{wt} \%)$ on all three supports and compared them with the patterns of the bimetallic counterparts (Fig. 1). The intensities of the diffraction peaks from all three supports decreased after doping with $10 \mathrm{wt} \% \mathrm{Cu}$ and $10 \mathrm{wt} \%$ Co in the monometallic catalysts. The intensities decreased further after doping simultaneously with $\mathrm{Cu}$ and Co. This implies that the crystallinities of the supports decreased as a result of high metal loadings. The diffraction

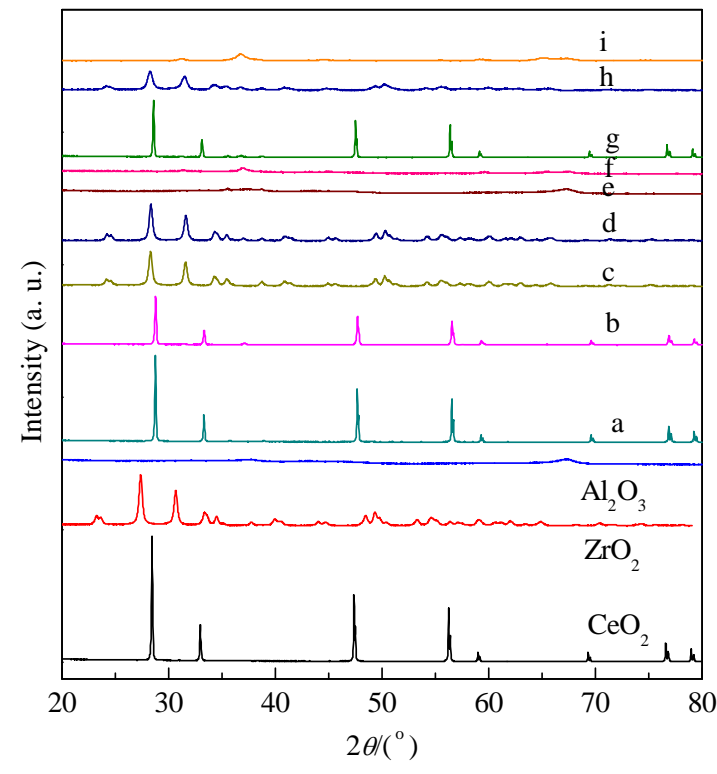

Fig. 1. Wide angle XRD patterns of supports $\mathrm{CeO}_{2}, \mathrm{ZrO}_{2}, \mathrm{Al}_{2} \mathrm{O}_{3}$, monometallic $\mathrm{Cu}(10 \mathrm{wt} \%)$ (a, c, e) and Co (10wt\%) (b, d, f) supported on $\mathrm{CeO}_{2}, \mathrm{ZrO}_{2}$ and $\mathrm{Al}_{2} \mathrm{O}_{3}$ respectively, and bimetallic $\mathrm{Cu}-\mathrm{Co}(\mathrm{Cu} / \mathrm{Co}=1)(\mathrm{g}, \mathrm{h}$ i) catalysts supported on $\mathrm{CeO}_{2}, \mathrm{ZrO}_{2}$ and $\mathrm{Al}_{2} \mathrm{O}_{3}$ respectively, calcined at $450{ }^{\circ} \mathrm{C}$.

patterns of the monometallic $\mathrm{Cu}$ and Co catalysts over all three supports showed diffraction peaks from $\mathrm{CuO}$ at $2 \theta=35.5^{\circ}$ and $38.7^{\circ}$, which are assigned to the (111) and (111) planes of monoclinic copper oxide (JCPDS 80-1917 and 45-0937), and from $\mathrm{Co}_{3} \mathrm{O}_{4}$ at $2 \theta=37^{\circ}, 44^{\circ}$, and $56^{\circ}$ (JCPDS 43-1003) [28,29].

Specific XRD patterns were observed for doped Cu-Co over all three supports (Fig. 1). For the calcined catalysts, either segregated $\mathrm{CuO}$ or a spinel oxide consisting of $\mathrm{Co}_{3} \mathrm{O}_{4} / \mathrm{CuCo}_{2} \mathrm{O}_{4}$ was clearly observed. Because of their similar cubic frameworks and unit cell parameters $\left(\mathrm{Co}_{3} \mathrm{O}_{4}, a=8.177 \AA\right.$ and $\mathrm{CuCo}_{2} \mathrm{O}_{4}, a=8.122 \AA$ ) , $\mathrm{Co}_{3} \mathrm{O}_{4}$ and $\mathrm{CuCo}_{2} \mathrm{O}_{4}$ are not easily distinguishable based on their XRD patterns [29]. The $\mathrm{Cu}-\mathrm{Co} / \mathrm{CeO}_{2}$ and $\mathrm{Cu}-\mathrm{Co} / \mathrm{ZrO}_{2}$ catalysts showed weak but clear diffraction peaks at $2 \theta=35.5^{\circ}$ and $38.7^{\circ}$, which are assigned to the (111) and (111) planes of monoclinic copper oxide (JCPDS 80-1917 and 45-0937), and diffraction peaks attributed to $\mathrm{Co}_{3} \mathrm{O}_{4}$ at $2 \theta=$ $37^{\circ}, 44^{\circ}$, and $56^{\circ}$ (JCPDS 43-1003). For $\mathrm{Cu}-\mathrm{Co} / \mathrm{Al}_{2} \mathrm{O}_{3}$, the weak diffraction peaks at $2 \theta=35.5^{\circ}$ and $38.7^{\circ}$ are attributed to highly dispersed $\mathrm{Cu}$ on porous $\mathrm{Al}_{2} \mathrm{O}_{3}$ [28,29]. The full-widths at half-maximum (FWHM) of the diffraction peak at $2 \theta=37^{\circ}$, which is attributed to $\mathrm{CuCoO}_{4}$, increased in the order $\mathrm{CeO}_{2}<$ $\mathrm{ZrO}_{2}<\mathrm{Al}_{2} \mathrm{O}_{3}$; this is because $\mathrm{Cu}-\mathrm{Co} / \mathrm{Al}_{2} \mathrm{O}_{3}$ has the smallest crystals.

In the case of the reduced catalysts (Fig. 2), $\mathrm{Cu}-\mathrm{Co} / \mathrm{ZrO}_{2}$ showed weak diffraction peaks from ( $\mathrm{fcc}$ ) $\mathrm{Cu}$ metal and $\mathrm{Cu}_{2} \mathrm{O}$. However, diffraction peaks from (fcc) $\mathrm{Cu}_{2} \mathrm{O}$ were not observed for the other two catalysts, i.e., $\mathrm{Cu}-\mathrm{Co} / \mathrm{CeO}{ }_{2}$ and $\mathrm{Cu}-\mathrm{Co} / \mathrm{Al}_{2} \mathrm{O}_{3}$; they only displayed diffraction peaks from (fcc) $\mathrm{Cu}$ metal. The FWHMs of the strongest peak, at $2 \theta=44.3^{\circ}$, decreased in the order of $\mathrm{CeO}_{2}<\mathrm{ZrO}_{2}<\mathrm{Al}_{2} \mathrm{O}_{3}$. This confirms that the metal particles in $\mathrm{Cu}-\mathrm{Co} / \mathrm{Al}_{2} \mathrm{O}_{3}$ are smaller than those in the other two catalysts. The sizes of the $\mathrm{Cu}$ metal crystallites in the reduced 


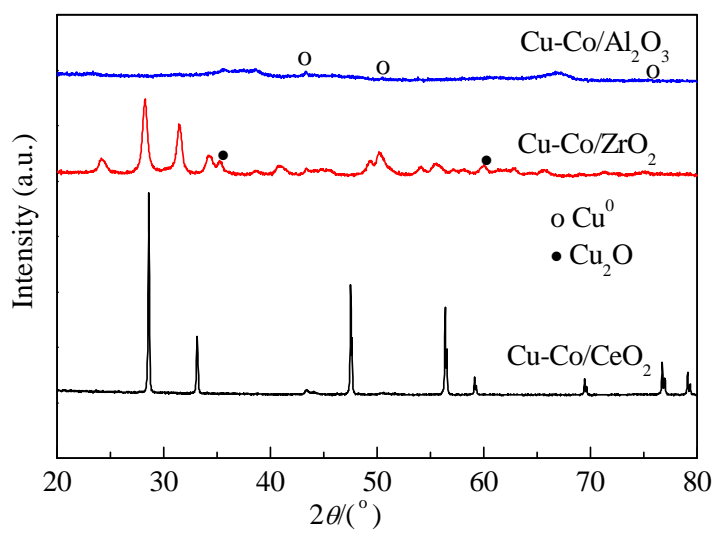

Fig. 2. Wide angle XRD patterns of $\mathrm{Cu}-\mathrm{Co}(\mathrm{Cu} / \mathrm{Co}=1)$ catalysts supported on $\mathrm{CeO}_{2}, \mathrm{ZrO}_{2}$ and $\mathrm{Al}_{2} \mathrm{O}_{3}$ reduced at $280{ }^{\circ} \mathrm{C}$.

catalysts were calculated using the Scherrer formula, based on the $\mathrm{Cu}(111)$ peak at $2 \theta=44.3^{\circ}$. The $\mathrm{CeO}_{2}$-supported catalyst had the largest $\mathrm{Cu}$ particles, of average size $25 \mathrm{~nm}$; the average $\mathrm{Cu}$ particle size for the $\mathrm{Al}_{2} \mathrm{O}_{3}$-supported catalyst was $15 \mathrm{~nm}$. The differences among the phases and crystallite sizes obtained with different supports can be attributed to the nature of the supports and/or metal-support interactions. The oxide supports used in this study interact weakly with $\mathrm{Cu}$ and $\mathrm{Co}$, and the order of the interaction strengths is $\mathrm{CeO}_{2}>\mathrm{ZrO}_{2}>\mathrm{Al}_{2} \mathrm{O}_{3}$ [38]. The stronger interactions between both the metals and $\mathrm{CeO}_{2}$ produced large segregated $\mathrm{CuO}$ and $\mathrm{Co}_{3} \mathrm{O}_{4}$ phases, whereas the strong interactions between copper and cobalt oxides and their weaker interactions with $\mathrm{Al}_{2} \mathrm{O}_{3}$ promoted formation of mixed copper-cobalt oxides. To understand the synergy between $\mathrm{Cu}$ and $\mathrm{Co}$ over $\mathrm{Al}_{2} \mathrm{O}_{3}$, the reduced bimetallic $\mathrm{Cu}$-Co $(\mathrm{Cu} / \mathrm{Co}=1)$ catalyst was compared with its monometallic counterparts, i.e. $\mathrm{Cu}(10 \mathrm{wt} \%) / \mathrm{Al}_{2} \mathrm{O}_{3}$ and $\mathrm{Co}(10 \mathrm{wt} \%) / \mathrm{Al}_{2} \mathrm{O}_{3}$ (reduced at 280 ${ }^{\circ} \mathrm{C}$ ), as shown in Fig. 3. The monometallic $\mathrm{Cu}$ catalyst contained large $\mathrm{Cu}$ crystals but the monometallic Co catalyst contained both oxide and metallic forms because of the reducing conditions used in this study. Monometallic $\mathrm{Co}_{3} \mathrm{O}_{4}$ is reduced at or above $450{ }^{\circ} \mathrm{C}$. In contrast to the monometallic catalysts, bimetallic $\mathrm{Cu}-\mathrm{Co} / \mathrm{Al}_{2} \mathrm{O}_{3}(\mathrm{Cu} / \mathrm{Co}=1)$ gave diffraction peaks from $\mathrm{Cu}$ and/or Co metal and partially reduced $\mathrm{CoO}_{x}$. The low intensities of the diffraction peaks from $\mathrm{Cu}$ metal suggest that co-doping of $\mathrm{Co}$ and $\mathrm{Cu}$ on porous $\mathrm{Al}_{2} \mathrm{O}_{3}$ significantly decreased the size of the metal crystallites. The particle size of monometallic $\mathrm{Cu}$, based on the peak at $44.3^{\circ}$, was $25-30 \mathrm{~nm}$. However, as reported earlier, the corresponding size was $15 \mathrm{~nm}$ for bimetallic $\mathrm{Cu}-\mathrm{Co} / \mathrm{Al}_{2} \mathrm{O}_{3}(\mathrm{Cu} / \mathrm{Co}=1)$. These observations are in good agreement with previously reported results for $\mathrm{Cu}$-Co catalysts [24-34].

\subsubsection{Textural properties}

The textural properties of the supports and the $\mathrm{Cu}$-Co catalysts supported by $\mathrm{CeO}_{2}, \mathrm{ZrO}_{2}$, and $\mathrm{Al}_{2} \mathrm{O}_{3}$ are summarized in Table 1. Because of its ordered porous structure, $\mathrm{Al}_{2} \mathrm{O}_{3}$ had the highest BET surface area, i.e. $166 \mathrm{~m}^{2} / \mathrm{g}$, and a pore volume of $0.54 \mathrm{~cm}^{3} / \mathrm{g}$. $\mathrm{CeO}_{2}$ had the lowest BET surface area, $\left(112 \mathrm{~m}^{2} / \mathrm{g}\right)$ and pore volume, $\left(0.28 \mathrm{~cm}^{3} / \mathrm{g}\right)$. The decreases in the surface

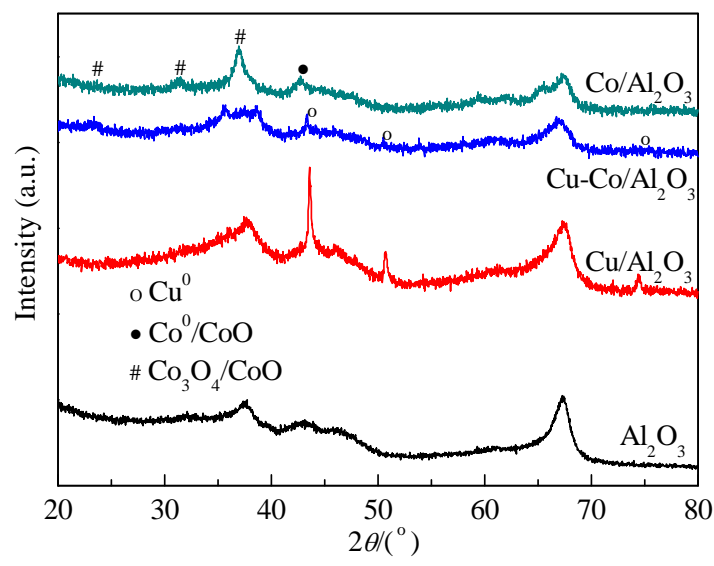

Fig. 3. Wide angle XRD patterns of $\mathrm{Al}_{2} \mathrm{O}_{3}$ supported mono ( $\mathrm{Cu} \& \mathrm{Co}$, $10 \mathrm{wt} \%)$ and bimetallic $\mathrm{Cu}-\mathrm{Co}(\mathrm{Cu} / \mathrm{Co}=1)$ reduced at $280{ }^{\circ} \mathrm{C}$ for comparison.

area, pore volume, and pore size of $\mathrm{CeO}_{2}$ after doping with $\mathrm{Cu}$ and Co were smaller than those for the other two supports; $\mathrm{Al}_{2} \mathrm{O}_{3}$ showed the largest reductions in surface area, pore volume, and pore size. The differences among the textural properties of the synthesized catalysts can be attributed to the nature of the supports and their interactions with both metals. The small decline in the pore volume and pore size of $\mathrm{CeO}_{2}$ after doping could be the result of deposition of metal particles on the external surface of the support rather than in the pores. However, the $\mathrm{Al}_{2} \mathrm{O}_{3}$-supported catalyst showed large reductions in pore volume and pore size; this can be attributed to deposition of metal particles on the surface and in the pores. It can be assumed that $\mathrm{CeO}_{2}$ can stabilize metal particles on the surface because it has strong interactions with both the metals used in this study. However, compared with $\mathrm{CeO}_{2}, \mathrm{Al}_{2} \mathrm{O}_{3}$ has weak interaction with $\mathrm{Cu}$ and $\mathrm{Co}$, and this may result in highly dispersed metal particles. These results are in agreement with those reported by Wang et al. [39], who suggested that strong interactions between $\mathrm{Cu}$ and $\mathrm{Co}$ and weaker interactions with $\mathrm{Al}_{2} \mathrm{O}_{3}$ lead to highly dispersed metal particles on porous $\mathrm{Al}_{2} \mathrm{O}_{3}$. This may result in a high surface area compared with those of the other two catalysts.

\subsubsection{Morphology}

TEM images of freshly reduced $\mathrm{Cu}-\mathrm{Co}(\mathrm{Cu} / \mathrm{Co}=1)$ on different supports are shown in Fig. 4. The dispersion and mor-

Table 1

Textural and structural characteristics of supports and supported Cu-Co catalysts.

\begin{tabular}{lccccccc}
\hline Samples & $\begin{array}{c}\mathrm{Cu}: \mathrm{Co}^{\mathrm{a}} \\
(\mathrm{wt} \%)\end{array}$ & $\begin{array}{c}\mathrm{Cu}: \mathrm{Co}^{\mathrm{b}} \\
(\mathrm{wt} \%)\end{array}$ & $\begin{array}{c}S_{\mathrm{BET}} \\
\left(\mathrm{m}^{2} / \mathrm{g}\right)\end{array}$ & $\begin{array}{c}V_{\mathrm{p}} \\
(\mathrm{mL} / \mathrm{g})\end{array}$ & $\begin{array}{c}D_{\mathrm{p}} \\
(\mathrm{nm})\end{array}$ & $\begin{array}{c}d_{\mathrm{p}} \\
(\mathrm{nm})\end{array}$ & Ref. \\
\hline $\mathrm{CeO}_{2}$ & & 112 & 0.28 & 3.2 & & \\
$\mathrm{ZrO}_{2}$ & & 132 & 0.38 & 4.6 & & \\
$\mathrm{Al}_{2} \mathrm{O}_{3}$ & & 166.1 & 0.54 & 6.6 & & {$[29]$} \\
$\mathrm{Cu}-\mathrm{Co} / \mathrm{CeO}_{2}$ & $10: 10$ & $9.2: 8.4$ & 82.6 & 0.18 & 2.6 & 25 & \\
$\mathrm{Cu}-\mathrm{Co} / \mathrm{ZrO}_{2}$ & $10: 10$ & $10.6: 10.2$ & 94.4 & 0.24 & 3.4 & 20 & \\
$\mathrm{Cu}-\mathrm{Co} / \mathrm{Al}_{2} \mathrm{O}_{3}$ & $10: 10$ & $10.4: 9.9$ & 113.5 & 0.32 & 4.6 & 15 & {$[29]$} \\
\hline a Loading ratio used in the synthesis. \\
b Evaluated by EDX analysis.
\end{tabular}




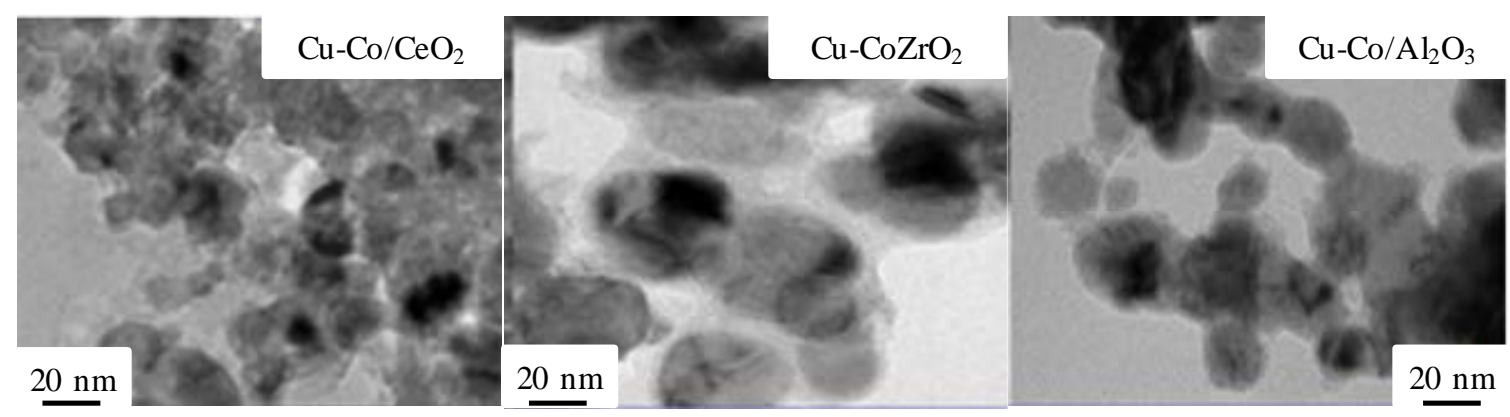

Fig. 4. $\mathrm{TEM}$ micrographs of $\mathrm{Cu}-\mathrm{Co}(\mathrm{Cu} / \mathrm{Co}=1)$ catalysts supported on $\mathrm{CeO}_{2}(\mathrm{a}), \mathrm{ZrO}_{2}(\mathrm{~b})$ and $\mathrm{Al}_{2} \mathrm{O}_{3}(\mathrm{c})$.

phology/ordering of the $\mathrm{Cu}$-Co nanoparticles on different supports vary depending on the nature of the support and the discrete interactions between the support and both $\mathrm{Cu}$ and $\mathrm{Co}$. Agglomerated large metal crystallites $(25-30 \mathrm{~nm})$ were observed in the $\mathrm{CeO}_{2}$-supported catalyst because of the strong interactions between $\mathrm{CeO}_{2}$ and the metal particles. Similar-sized but segregated, non-uniformly distributed $\mathrm{Cu}$-Co nanoparticles were observed on $\mathrm{ZrO}_{2}$. $\mathrm{Cu}-\mathrm{Co} / \mathrm{Al}_{2} \mathrm{O}_{3}$ had well dispersed, ordered, uniformly spherical small nanoparticles. The metal particles in $\mathrm{Cu}-\mathrm{Co} / \mathrm{Al}_{2} \mathrm{O}_{3}$ were mainly of uniform size about $20 \mathrm{~nm}$. This morphology/ordering of $\mathrm{Cu}$-Co nanoparticles on $\mathrm{CeO}_{2}, \mathrm{ZrO}_{2}$, and $\mathrm{Al}_{2} \mathrm{O}_{3}$ can be explained based on a combination of a porous structure and metal-support interactions.

The more uniform distributions of $\mathrm{Cu}$-Co particles on the $\mathrm{Al}_{2} \mathrm{O}_{3}$ support can be ascribed to the interactions between uniformly porous $\mathrm{Al}_{2} \mathrm{O}_{3}$ and both $\mathrm{Cu}$ and $\mathrm{Co}$ species being weaker than the metal-support interactions in the other cases [29].

\subsubsection{Reductive properties}

The reductive properties of $\mathrm{Cu}-\mathrm{Co} / \mathrm{CeO}_{2}, \mathrm{Cu}-\mathrm{Co} / \mathrm{ZrO}_{2}$, and $\mathrm{Cu}-\mathrm{Co} / \mathrm{Al}_{2} \mathrm{O}_{3}$ were investigated using $\mathrm{H}_{2}$-TPR. Metal-support interactions play a vital role in stabilizing and reducing metal oxides to metallic sites. In particular, for bimetallic catalytic systems, the interactions between each metal component and the support significantly affects the chemical environment of the metals and/or the reduction temperature. Weakly interacting metal oxide species are easily reduced to the metallic state [38]. Conversely, if the metal oxides are strongly adsorbed on the support, they are difficult to reduce, and this leads to incomplete reduction and formation of low-valence metals $[37,38]$. The reductive properties of the $\mathrm{Cu}-\mathrm{Co}(\mathrm{Cu} / \mathrm{Co}=1)$ catalysts supported on $\mathrm{CeO}_{2}$ and $\mathrm{ZrO}_{2}$ were determined using $\mathrm{H}_{2}$-TPR and the profiles were compared with that of $\mathrm{Cu}-\mathrm{Co} / \mathrm{Al}_{2} \mathrm{O}_{3}$ [29] (Fig. 5). The nature of the support significantly affected the reducibility of the bimetallic catalysts. The differences among the reduction temperatures showed that the $\mathrm{CeO}_{2}$ (broad hump at $220-370{ }^{\circ} \mathrm{C}$ ) support had stronger interaction with both metals. $\mathrm{Al}_{2} \mathrm{O}_{3}$ and $\mathrm{ZrO}_{2}$ showed broad humps which were deconvoluted to several peaks. The TPR profile of the $\mathrm{ZrO}_{2}$-supported catalyst showed three major reduction peaks. The first peak, at $200{ }^{\circ} \mathrm{C}$, is attributed to the reduction of small $\mathrm{CuO}$ particles, which interact weakly with $\mathrm{ZrO}_{2}$. The second peak, at $250-370{ }^{\circ} \mathrm{C}$, is ascribed to the reduction of larger $\mathrm{CuO}$ particles, which are strongly attached to $\mathrm{ZrO}_{2}$. The third peak, at around $400{ }^{\circ} \mathrm{C}$, is attributed to the reduction of $\mathrm{Co}_{3} \mathrm{O}_{4}$ species on the $\mathrm{ZrO}_{2}$ surface.

The TPR profile for $\mathrm{Cu}-\mathrm{Co} / \mathrm{Al}_{2} \mathrm{O}_{3}$ was different from those for the other two catalysts, and reduction occurred at a lower temperature; this is ascribed to the reduction of mixed copper-cobalt oxides and small $\mathrm{Cu}$ particles. These observations are supported by the XRD and TEM results. The presence of multiple reduction peaks indicates two-step reduction of $\mathrm{Cu}$ and partial reduction of $\mathrm{CuCo}_{2} \mathrm{O}_{4} / \mathrm{Co}_{3} \mathrm{O}_{4}$ [16,35]. Among the three supports, $\mathrm{Al}_{2} \mathrm{O}_{3}$ has the weakest interactions with the copper-cobalt oxide phases and this enhances the reducibility of the copper oxides and mixed $\mathrm{CuCo}_{2} \mathrm{O}_{4}$, which increases the number of $\mathrm{Cu}-\mathrm{CoO}_{x}$ sites in $\mathrm{Cu}-\mathrm{Co} / \mathrm{Al}_{2} \mathrm{O}_{3}$. To clarify the effect of synergy between $\mathrm{Cu}$ and $\mathrm{Co}$ on the reductive properties, the reduction profiles of monometallic $\mathrm{Cu}(10 \mathrm{wt} \%) / \mathrm{Al}_{2} \mathrm{O}_{3}$ and $\mathrm{Co}$ (10 wt\%) $/ \mathrm{Al}_{2} \mathrm{O}_{3}$ were also obtained (Fig. 5), and compared with those of their bimetallic counterparts. The differences among these reductive behaviours were discussed at length in our previous work [29]. Table 2 shows the experimental $\mathrm{H}_{2}$ consumptions during TPR. It can be deduced that $\mathrm{Co}$ and $\mathrm{Cu}$ are both essentially completely reduced by $400{ }^{\circ} \mathrm{C}$ on all three supports, with $\mathrm{Cu}-\mathrm{Co} / \mathrm{CeO}_{2}$ being slightly less reduced (82\%) compared with the other two (88\% and $96 \%$ ).

\subsubsection{Surface acidity}

The surface acidities of the bimetallic $\mathrm{Cu}-\mathrm{Co}(\mathrm{Cu} / \mathrm{Co}=1)$ catalysts supported on $\mathrm{CeO}_{2}$ and $\mathrm{ZrO}_{2}$ were determined using

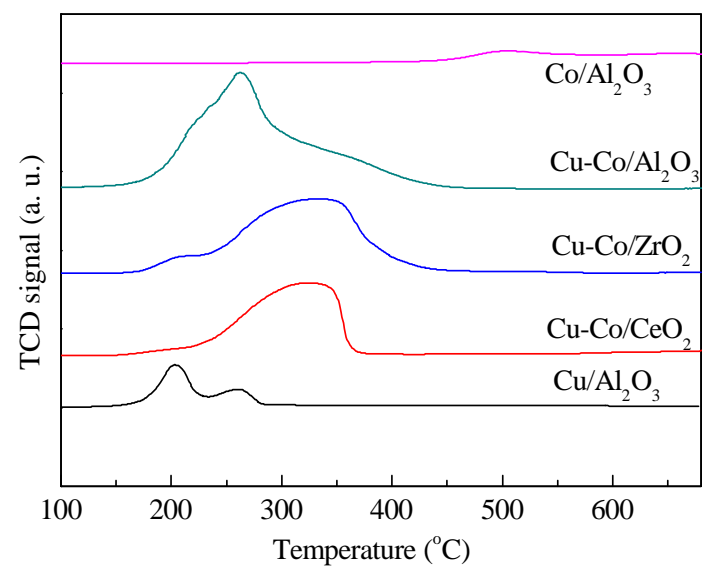

Fig. 5. $\mathrm{H}_{2}$-TPR patterns of $\mathrm{Cu}-\mathrm{Co}(\mathrm{Cu} / \mathrm{Co}=1)$ catalysts supported on $\mathrm{CeO}_{2}, \mathrm{ZrO}_{2}$ and $\mathrm{Al}_{2} \mathrm{O}_{3}$ calcined at $450{ }^{\circ} \mathrm{C}$. 
Table 2

Quantitative Hydrogen consumption during TPR.

\begin{tabular}{lcccc}
\hline Samples & $\begin{array}{c}\mathrm{Cu} / \mathrm{Co}^{\mathrm{a}} \\
\text { (wt\%/wt\%) }\end{array}$ & $\begin{array}{c}\mathrm{H}_{2} \text { consumption } \\
\text { (mmol/g.cat) }\end{array}$ & $\begin{array}{c}\text { Metal re- } \\
\text { duced (\%) }\end{array}$ & Ref. \\
\hline $\mathrm{Cu}-\mathrm{Co} / \mathrm{CeO}_{2}$ & 1 & 32.6 & 82 & - \\
$\mathrm{Cu}-\mathrm{Co} / \mathrm{ZrO}_{2}$ & 1 & 44.3 & 88 & - \\
$\mathrm{Cu}-\mathrm{Co} / \mathrm{Al}_{2} \mathrm{O}_{3}$ & 1 & 53.8 & 96 & {$[29]$} \\
\hline
\end{tabular}

a Loading ratio used in the synthesis.

$\mathrm{NH}_{3}$-TPD and the results were compared with those for $\mathrm{Cu}-\mathrm{Co} / \mathrm{Al}_{2} \mathrm{O}_{3}$ (Fig. 6 and Table 3). Generally, the strengths of the acidic sites, based on the $\mathrm{NH}_{3}$ desorption temperature, can be classified as weak $\left(<250^{\circ} \mathrm{C}\right)$, medium $\left(250-400^{\circ} \mathrm{C}\right)$, and strong $\left(>400{ }^{\circ} \mathrm{C}\right.$ ) acidic sites. The overall acidity of a catalyst can be calculated from the relative peak areas in the $\mathrm{NH}_{3}$-desorption curves [29]. $\mathrm{Cu}-\mathrm{Co} / \mathrm{CeO}_{2}(\mathrm{Cu} / \mathrm{Co}=1)$ had few weak and strong acidic sites, and had only medium acidity. $\mathrm{Cu}-\mathrm{Co} / \mathrm{Al}_{2} \mathrm{O}_{3}(\mathrm{Cu} / \mathrm{Co}$ $=1$ ) showed three peaks (at 145,335 , and $555^{\circ} \mathrm{C}$ ), which can be ascribed to $\mathrm{NH}_{3}$ desorption from weak, medium, and strong acidic sites. $\mathrm{Cu}-\mathrm{Co} / \mathrm{ZrO}_{2}(\mathrm{Cu} / \mathrm{Co}=1)$ showed two peaks (minor $100-250{ }^{\circ} \mathrm{C}$, major $350-550{ }^{\circ} \mathrm{C}$ ), which can be ascribed to $\mathrm{NH}_{3}$ desorption by weak and strong acidic sites (Fig. 6 and Table 3). A comparison of the results for the three catalysts shows that $\mathrm{Cu}-\mathrm{Co} / \mathrm{Al}_{2} \mathrm{O}_{3}(\mathrm{Cu} / \mathrm{Co}=1)$ had the maximum acidity, i.e. 0.49 $\mathrm{mmol} / \mathrm{g}$ cat. The order of the total acidities was $\mathrm{Al}_{2} \mathrm{O}_{3}>\mathrm{ZrO}_{2}>$ $\mathrm{CeO}_{2}$. It is worth noting that five different types of $\mathrm{OH}$ groups are present on the surface of $\gamma-\mathrm{Al}_{2} \mathrm{O}_{3}$, giving a net electric charge $(\sigma)$, depending on the number of $\mathrm{Al}$ neighbours and $\mathrm{Al}$ coordination $[40,41]$. The removal of $\mathrm{OH}$ groups during high-temperature treatment (calcination) creates unsaturated surface cations, with mainly tetrahedrally [Al(IV)] and octahedrally [Al(VI)] coordinated $\mathrm{Al}[42,43]$. Both Lewis and Brønsted acidic sites may therefore be present on $\mathrm{Al}_{2} \mathrm{O}_{3}$, depending on the degree of dehydration.

\subsection{Catalytic activity}

\subsubsection{Catalyst screening for HMF hydrogenation to DMF}

We previously reported a liquid-phase hydrogenation of FAL to 2-MF using a highly efficient non-noble metal, environmentally benign, bimetallic $\mathrm{Cu}-\mathrm{Co}$ catalyst [29]. The advantage of this catalytic system, which was prepared using an impregnation method, over other $\mathrm{Cu}$-based catalysts has been thoroughly discussed. In our previous work, we found that $\mathrm{SiO}_{2}$ and H-ZSM-5 supports gave low selectivities for C-O hydrogenolysis. In this study, we therefore used materials which can stabilize metal dispersion and improve oxygen storage, i.e. $\mathrm{CeO}_{2}$ and $\mathrm{ZrO}_{2}$, as supports for $\mathrm{Cu}-\mathrm{Co}(\mathrm{Cu} / \mathrm{Co}=1)$ and compared the per-

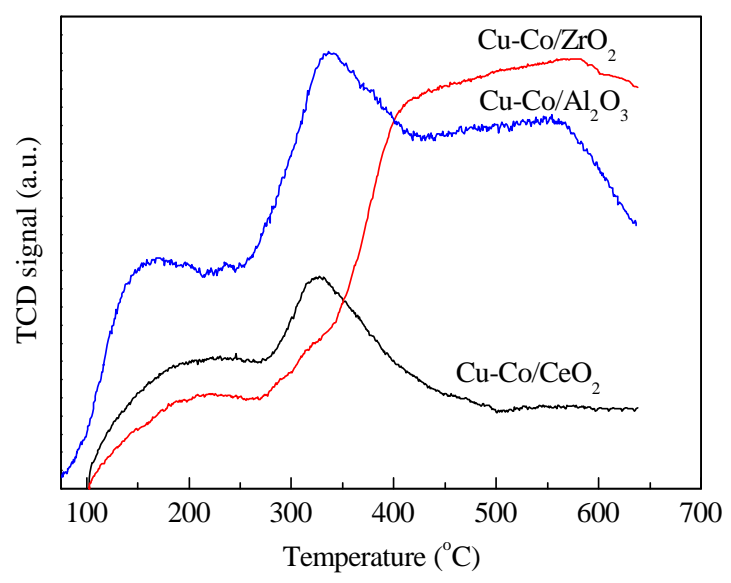

Fig. 6. $\mathrm{NH}_{3}$-TPD patterns of $\mathrm{Cu}-\mathrm{Co}(\mathrm{Cu} / \mathrm{Co}=1)$ catalysts supported on $\mathrm{CeO}_{2}, \mathrm{ZrO}_{2}$ and $\mathrm{Al}_{2} \mathrm{O}_{3}$ calcined at $450{ }^{\circ} \mathrm{C}$.

formance of these catalysts with that of $\mathrm{Cu}-\mathrm{Co} / \mathrm{Al}_{2} \mathrm{O}_{3}(\mathrm{Cu} / \mathrm{Co}=$ 1) in the hydrogenation/hydrogenolysis of HMF to DMF at 200 ${ }^{\circ} \mathrm{C}$ and 3.0 MPa (Fig. 7). The support plays a significant role in the selective hydrogenation/hydrogenolysis of HMF to DMF. $\mathrm{Cu}-\mathrm{Co} / \mathrm{CeO}_{2}$ showed the lowest catalytic activity (78\% conversion) and $\mathrm{Cu}-\mathrm{Co} / \mathrm{Al}_{2} \mathrm{O}_{3}$ showed the highest catalytic activity (98\% conversion) in HMF hydrogenation. The order of the catalytic activities was $\mathrm{CeO}_{2}<\mathrm{ZrO}_{2}<\mathrm{Al}_{2} \mathrm{O}_{3}$. $\mathrm{HMF}$ contains three functional groups, namely $\mathrm{C}=\mathrm{O}, \mathrm{O}-\mathrm{H}$, and the furan ring (Scheme 1). Over Cu catalysts, HMF hydrogenation proceeds by reduction of the $\mathrm{C}=0$ bond to give the diol intermediate $\mathrm{BHMF}$. Further hydrogenolysis of BHMF leads to the formation of DMF via another intermediate, i.e. 5-MFOL [20-23]. Nagaraja et al. [44] proposed that the presence of a larger amount of metallic $\mathrm{Cu}$ than of $\mathrm{CuO}$ promoted reduction of the $\mathrm{C}=\mathrm{O}$ bond in $\mathrm{FAL}$ to give furfuryl alcohol. In our previous work, we also observed that the conversion of FAL to furfuryl alcohol via $\mathrm{C}=0$ reduction increased with increasing amount of surface metallic $\mathrm{Cu}$ [27]. The activities of all three catalysts used in this study can therefore be explained based on (1) the degree of reduction, i.e. the amount of surface metallic $\mathrm{Cu}$ species, indicated by $\mathrm{H}_{2}$ consumption during TPR, and (2) the number of copper-cobalt mixed oxide sites available. $\mathrm{Cu}-\mathrm{Co} / \mathrm{CeO}_{2}$ gave the lowest $\mathrm{H}_{2}$ consumption, and $\mathrm{Cu}-\mathrm{Co} / \mathrm{Al}_{2} \mathrm{O}_{3}$ consumed the highest volume of $\mathrm{H}_{2}$.

In terms of product selectivity, the main compounds identified in the liquid reaction products were BHMF, 5-MF, 5-MFOL, and DMF, over all three catalysts. However, the selectivity for the desired product (DMF) is affected by the support, the second metal, or both. For example, $\mathrm{Cu}-\mathrm{Co} / \mathrm{CeO}_{2}$ gave the highest

Table 3

Acidity of bi-metallic $\mathrm{Cu}$-Co catalysts supported on $\mathrm{CeO}_{2}, \mathrm{ZrO}_{2}$, and $\mathrm{Al}_{2} \mathrm{O}_{3}$, using ammonia-TPD method.

\begin{tabular}{|c|c|c|c|c|c|c|}
\hline \multirow{2}{*}{ Samples } & \multirow{2}{*}{$\begin{array}{c}\mathrm{Cu} / \mathrm{Co}^{*} \\
(\mathrm{wt} \% / \mathrm{wt} \%)\end{array}$} & \multicolumn{3}{|c|}{ Amount of ammonia desorbed (mmol/g.cat) } & \multirow{2}{*}{$\begin{array}{l}\text { Total Acidity } \\
\text { (mmol/g.cat) }\end{array}$} & \multirow{2}{*}{ Ref. } \\
\hline & & $<200^{\circ} \mathrm{C}$ & $250-450^{\circ} \mathrm{C}$ & $>450^{\circ} \mathrm{C}$ & & \\
\hline $\mathrm{Cu}-\mathrm{Co} / \mathrm{CeO}_{2}$ & 1 & 0.03 & 0.18 & 0.04 & 0.25 & - \\
\hline $\mathrm{Cu}-\mathrm{Co} / \mathrm{ZrO}_{2}$ & 1 & 0.08 & 0.04 & 0.28 & 0.40 & - \\
\hline $\mathrm{Cu}-\mathrm{Co} / \mathrm{Al}_{2} \mathrm{O}_{3}$ & 1 & 0.13 & 0.21 & 0.14 & 0.49 & [29] \\
\hline
\end{tabular}

* Loading ratio used in the synthesis. 


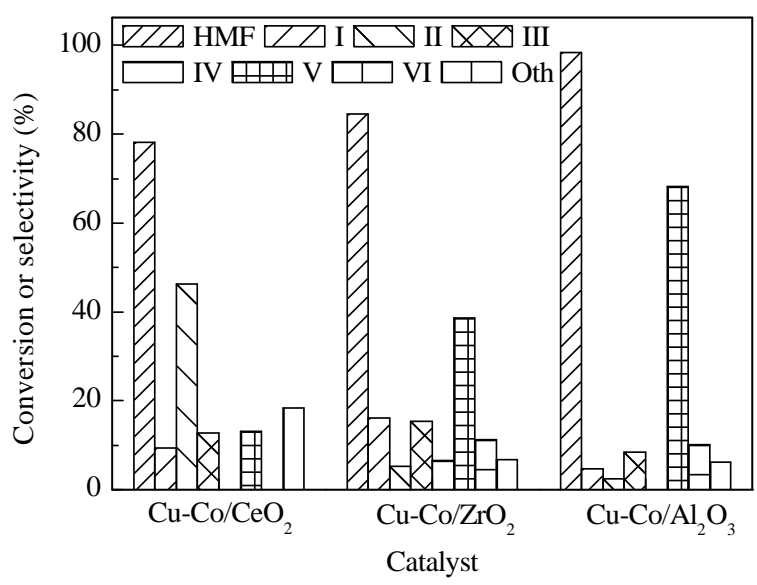

Fig. 7. Catalytic activity for hydrogenolysis of HMF over supported bi-metallic copper-cobalt catalyst. Reaction conditions: $200{ }^{\circ} \mathrm{C}, 3.0 \mathrm{MPa}$, $8 \mathrm{~h}$, Catalyst $0.5 \mathrm{~g}$, HMF $2.5 \mathrm{mmol}$, THF $20 \mathrm{~mL}$. I-5-Methylfurfural (5-MF), II-bis(hydroxymeth yl-furan) (BHMF), III-5-methylfurfuryl alcohol (5-MFOL), IV-5,5-oxybis(methylene)bis(2-methylfuran), V-2,5-dimethylfuran (DMF), VI-2,5-dimethyltetrahydrofuran (DMTHF), Oth = FOL, MF and few of unknown products.

selectivity for BHMF because of preferential reduction of the $\mathrm{C}=\mathrm{O}$ bond in HMF. Small amounts of hydrogenolysis products such as 5-MF, 5-MFOL, and DMF, and small amounts of the products FOL and MF, which were produced by decarbonylation followed by hydrogenolysis, were also detected. $\mathrm{Cu}-\mathrm{Co} / \mathrm{Al}_{2} \mathrm{O}_{3}$ was the most active in polarizing $\mathrm{O}-\mathrm{H}$ and $\mathrm{C}-\mathrm{O}$ bonds, resulting in DMF production via sequential hydrogenation/hydrogenolysis of HMF. These results show that $\mathrm{Cu}$ effectively promotes hydrogenation and moderately promotes hydrogenolysis. In addition, $\mathrm{Cu}$ can break the $\mathrm{C}=\mathrm{O}$ bond during hydrogenation of FAL and HMF $[21,28,44]$. It has also been reported that $\mathrm{Cu}$ metal gives selective production of propylene glycol via glycerol hydrogenolysis [43]. Sithisa et al. [44] proposed that aldehydes were preferentially adsorbed in the $\eta^{1}(0)$ configuration on $\mathrm{Cu}$ metal, which allows interactions between surface $\mathrm{Cu}$ and the oxygen of the FAL carbonyl group, to yield furfuryl alcohol. It has also been reported that surface $\mathrm{Cu}$ can induce $\mathrm{O}-\mathrm{H}$ bond scission to form stable alkoxide $\left(\mathrm{CH}_{3} \mathrm{O}\right)$ intermediates during methanol decomposition [45].

The above findings suggest that the increased selectivity of $\mathrm{Cu}-\mathrm{Co} / \mathrm{Al}_{2} \mathrm{O}_{3}$ for DMF production via $\mathrm{C}-\mathrm{O}$ and $\mathrm{O}-\mathrm{H}$ hydrogenolysis can be attributed to synergy between surface metallic $\mathrm{Cu}$ sites and partially reduced $\mathrm{CoO}_{x}$ sites. The XRD and TPR results show that $\mathrm{Cu}-\mathrm{Co} / \mathrm{Al}_{2} \mathrm{O}_{3}$ has the maximum amounts of surface metallic $\mathrm{Cu}$ and mixed oxide phases, resulting in an increased rate of hydrogenolysis [29]. It has been reported that the reduced forms of spinel $\mathrm{CuCoO}_{4}$ catalysts involve metallic $\mathrm{Cu}$ dispersed on $\mathrm{CoO}_{x}[34,35]$. It has also been reported that early-transition-metal oxides such as $\mathrm{ReO}_{x}, \mathrm{MoO}_{x}$, and $\mathrm{CoO}_{x}$ are effective catalysts in the hydrogenolysis of biomass-derived components $[35,36]$. Previous studies $[47,48]$ have shown that dissociative adsorption of $\mathrm{H}_{2}$ on $\mathrm{Cu}(0)$ has a low activation energy [49]. Similar effects have been observed for promotion of $\mathrm{Cu}$ catalysts with noble metals [50]. Recently, our group reported that an increase in the Co loading increased $\mathrm{Cu}$ disper- sion because of the strong interactions between $\mathrm{Cu}$ and Co. A combination of $\mathrm{Cu}-\mathrm{CoO}_{x}$ was found to be effective in the one-step hydrogenation of FAL to 2-MF via reduction of the $\mathrm{C}=\mathrm{O}$ bond followed by $\mathrm{C}-\mathrm{O}$ hydrogenolysis [29]. These previous reports and the present experimental findings suggest that the improved dispersion of $\mathrm{Cu}$ in the presence of $\mathrm{Co}$ and the synergy between $\mathrm{Cu}$ and $\mathrm{CoO}_{x}$ species as a result of strong interactions between $\mathrm{Cu}$ and $\mathrm{Co}$ facilitate the hydrogenolysis of $\mathrm{HMF}$ to DMF. This is supported by the XRD, BET, and $\mathrm{H}_{2}$-TPR results. Metallic $\mathrm{Cu}$ and mixed $\mathrm{Cu}$-Co particles can therefore activate $\mathrm{H}_{2}$ to enable partial reduction of $\mathrm{Co}_{3} \mathrm{O}_{4}$, which is difficult to reduce at low temperatures. This reducibility of the bimetallic catalysts is responsible for the enhanced activity of the $\mathrm{Cu}-\mathrm{Co} / \mathrm{Al}_{2} \mathrm{O}_{3}$ catalyst.

$\mathrm{Cu}-\mathrm{Co} / \mathrm{ZrO}_{2}$ had low selectivity for DMF (about $40 \%$ ) and produced a combination of ring-saturation and over-hydrogenolysis products such as DMTHF and other by-products. The properties of $\mathrm{ZrO}_{2}$ and the presence of strong acidic sites may be responsible for this behaviour; the strong acidic sites may cause side reactions such as ring opening or ring saturation. Bui et al. [51] reported that ring opening by hydrolytic cleavage of the furanic $\mathrm{C}-\mathrm{O}$ bond was usually promoted by Brønsted acidic sites in acidic materials. In addition, traces of 5,5-oxybis(methylene)bis(2-methylfuran), formed by dehydration of 5-MOL, were also observed with $\mathrm{Cu}-\mathrm{Co} / \mathrm{ZrO}_{2}$. This is in agreement with a previous report [15].

We studied the hydrogenolysis of 5-methylfurfural (5-MF) over the same catalysts and under the same reaction conditions (Fig. 8) to explore the reaction pathways and clarify the reasons for the superior hydrogenolysis activities of some of the catalysts. The hydrogenolysis activity of $\mathrm{Cu}-\mathrm{Co} / \mathrm{CeO}_{2}$ was inferior to those of the other two catalysts. About 86\% 5-MF was converted over $\mathrm{Cu}-\mathrm{Co} / \mathrm{CeO}_{2}$, with $32 \%$ selectivity for DMF. The major product selectivity was for 5-MFOL (48\%), formed via reduction of the $\mathrm{C}=0$ bond in $5-\mathrm{MF}$. Following the trend observed for $\mathrm{HMF}$ hydrogenation, $\mathrm{Cu}-\mathrm{Co} / \mathrm{Al}_{2} \mathrm{O}_{3}$ showed excellent hydrogenolysis activity and produced about $82 \%$ DMF with

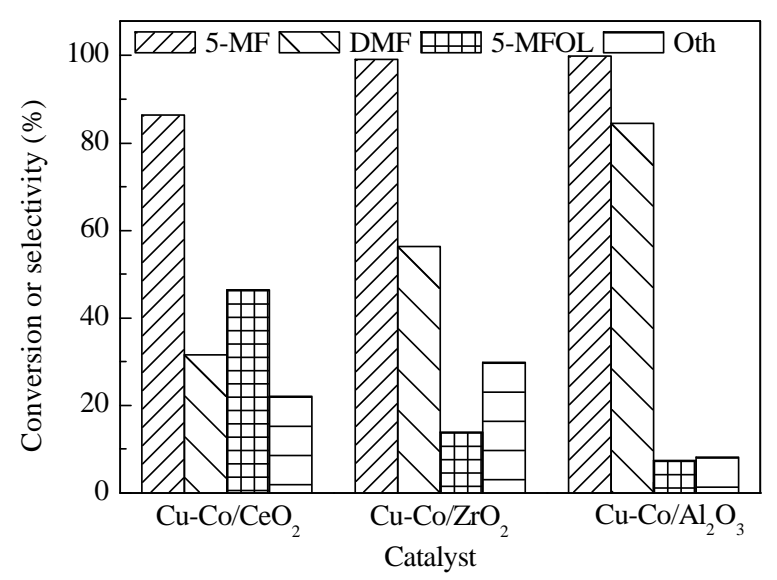

Fig. 8. Catalytic activity for hydrogenolysis of 5-methylfurfural over supported bi-metallic copper-cobalt catalysts. Reaction conditions: 200 ${ }^{\circ} \mathrm{C}$, $3.0 \mathrm{MPa}, 8 \mathrm{~h}$, Catalyst $0.5 \mathrm{~g}$, 5-MF $2.5 \mathrm{mmol}$, THF $20 \mathrm{~mL}$. Oth=5,5-oxybis(methylene)bis(2-methylfuran), 2,5-dimethyltetrahydrofuran (DMTHF), FOL, MF and few of unknown products. 
99\% conversion of 5-MF. However, although 99\% conversion of $5-\mathrm{MF}$ was achieved over $\mathrm{Cu}-\mathrm{Co} / \mathrm{ZrO}_{2}$, the selectivity for DMF (56\%) was low and large amounts of ring-saturation and ring-opening products were obtained. These results are in agreement with those obtained for one-step hydrogenolysis of HMF to DMF.

\subsubsection{Effects of $\mathrm{Cu} / \mathrm{Co}$ molar ratio on $\mathrm{HMF}$ hydrogenolysis}

The effect of the $\mathrm{Cu} / \mathrm{Co}$ molar ratio on the catalytic activity of bimetallic $\mathrm{Cu}-\mathrm{Co} / \mathrm{Al}_{2} \mathrm{O}_{3}$ was investigated by studying catalysts with various molar ratio $(\mathrm{Cu} / \mathrm{Co}=1,2$, and 4$)$ at $200{ }^{\circ} \mathrm{C}$ and 3.0 MPa. The results were compared with those for the monometallic $\mathrm{Cu}(10 \mathrm{wt} \%) / \mathrm{Al}_{2} \mathrm{O}_{3}$ and $\mathrm{Co}(10 \mathrm{wt} \%) / \mathrm{Al}_{2} \mathrm{O}_{3}$ counterparts (Table 4). The catalytic activity of Co (10 wt\%) $/ \mathrm{Al}_{2} \mathrm{O}_{3}$ was low, which confirms that $\mathrm{Co}_{3} \mathrm{O}_{4}$ species alone have little effect on HMF hydrogenolysis under the present conditions. This result is in agreement with that reported by $\mathrm{Zu}$ et al. [15], who found that $\mathrm{Co}_{3} \mathrm{O}_{4}$ had low catalytic activity in $\mathrm{HMF}$ hydrogenation. When $10 \mathrm{wt} \% \mathrm{Cu} / \mathrm{Al}_{2} \mathrm{O}_{3}$ was used, $\mathrm{BHMF}$, formed via activation of the carbonyl group, was the major product (45.5\%). However, the bimetallic catalysts gave lower selectivities for BHMF and increased selectivities for DMF; the DMF selectivity reached a maximum of about $68.4 \%$ over $\mathrm{Cu}-\mathrm{Co} / \mathrm{Al}_{2} \mathrm{O}_{3}(\mathrm{Cu} / \mathrm{Co}=1)$. BHMF was the main intermediate formed over all the catalysts, and it was converted to DMF via 5-MF and MFOL by subsequent hydrogenation and hydrogenolysis under the present conditions [22-26]. It can be deduced that hydrogenation of the $\mathrm{C}=\mathrm{O}$ bond followed by hydrogenolysis of $\mathrm{C}-\mathrm{O}$ and $\mathrm{O}-\mathrm{H}$ bonds in $\mathrm{HMF}$ is favoured at higher temperatures because of activation of the $\mathrm{C}-\mathrm{O}$ and $\mathrm{O}-\mathrm{H}$ bonds, which results in formation of DMF as the major product and BHMF, MFA, and MFOL as minor products over bimetallic $\mathrm{Cu}$-Co catalysts [46]. These results can be explained based on previously reported XRD, $\mathrm{H}_{2}$-TPR, and X-ray absorption near-edge structure studies, which showed that the amounts of surface metallic $\mathrm{Cu}$ and mixed $\mathrm{Cu}$-Co phases increased with increasing Co loading; this is responsible for the enhanced hydrogenolysis activity of the bimetallic catalysts [29].

We then studied the effects of temperature, $\mathrm{H}_{2}$ pressure, and time on reactions using the $\mathrm{Cu}-\mathrm{Co} / \mathrm{Al}_{2} \mathrm{O}_{3}(\mathrm{Cu} / \mathrm{Co}=1)$ catalyst to improve the DMF yield.

\subsection{Effects of operating parameters}

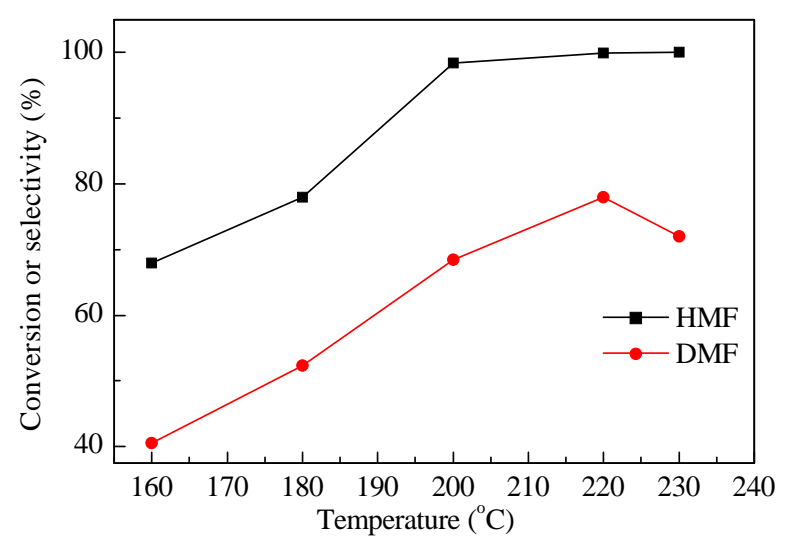

Fig. 9. Effect of temperature on the conversion of HMF to DMF over $\mathrm{Cu}-\mathrm{Co} / \mathrm{Al}_{2} \mathrm{O}_{3}(\mathrm{Cu} / \mathrm{Co}=1)$. Reaction conditions: $3.0 \mathrm{MPa}, 8 \mathrm{~h}$, Catalyst $0.5 \mathrm{~g}$, HMF $2.5 \mathrm{mmol}$, THF $20 \mathrm{~mL}$.

\subsubsection{Effects of temperature}

The effect of temperature on the selective hydrogenolysis of HMF to DMF was studied over the temperature range 160-230 ${ }^{\circ} \mathrm{C}$ at a constant $\mathrm{H}_{2}$ pressure of $3.0 \mathrm{MPa}$ (Fig. 9). The HMF conversion was low $(68 \%)$ at $160^{\circ} \mathrm{C}$, but increased with increasing temperature. It reached the maximum, i.e. $100 \%$ at $220{ }^{\circ} \mathrm{C}$, and remained constant with further temperature increases to 230 ${ }^{\circ} \mathrm{C}$. These results can be attributed to an increase in the reaction rate because of facilitation of $\mathrm{C}=\mathrm{O}$ bond breaking over metallic $\mathrm{Cu}$, resulting in increased activation of molecular $\mathrm{H}_{2}$ in the reaction mixture [22,23]. Hydrogenation of the $\mathrm{C}=\mathrm{C}$ bond (bond energy $=615 \mathrm{~kJ} / \mathrm{mol}$ ) is easier than $\mathrm{C}=0$ bond (bond energy = $715 \mathrm{~kJ} / \mathrm{mol}$ ) hydrogenation [45]. However, the presence of the conjugated furan ring makes hydrogenation of the $\mathrm{C}=0$ bond easier than $\mathrm{C}=\mathrm{C}$ bond hydrogenation in the selective hydrogenation of HMF to DMF, which is generally promoted at higher temperatures [46]. At $160{ }^{\circ} \mathrm{C}$ the selectivity for DMF was low (40.6\%), with formation of by-products such as BHMF, 5-MF, and 5-MFOL. However, with increasing temperature, the selectivity for DMF improved significantly and reached a maximum of $78 \%$ at $220^{\circ} \mathrm{C}$. It is worth noting that hydrogenation of the $\mathrm{C}=\mathrm{O}$ bond in $\mathrm{HMF}$ was favoured at low temperatures over $\mathrm{Cu}$ catalysts because of the higher activation energies of $\mathrm{C}-\mathrm{O}$ and $\mathrm{O}-\mathrm{H}$, resulting in the formation of BHMF as a major product. However, higher temperatures promote $\mathrm{C}-\mathrm{O}$ and $\mathrm{O}-\mathrm{H}$ hydrogenolysis, which results in further conversion of BHMF to DMF.

Table 4

Effect of $\mathrm{Cu} / \mathrm{Co}$ molar ratio on hydrogenolysis of $\mathrm{HMF}$.

\begin{tabular}{|c|c|c|c|c|c|c|c|}
\hline \multirow{2}{*}{ Catalyst } & \multirow{2}{*}{$\begin{array}{c}\mathrm{Cu} / \mathrm{Co}^{*} \\
(\mathrm{wt} \% / \mathrm{wt} \%)\end{array}$} & \multirow{2}{*}{$\begin{array}{c}\text { HMF Conversion } \\
(\%)\end{array}$} & \multicolumn{5}{|c|}{ Selectivity (\%) } \\
\hline & & & DMF & BHMF & 5-MF & 5-MFOL & Oth \\
\hline $\mathrm{Cu} / \mathrm{Al}_{2} \mathrm{O}_{3}$ & - & 92.7 & 38.5 & 45.5 & 3.5 & 2.5 & 10.0 \\
\hline $\mathrm{Cu}-\mathrm{Co} / \mathrm{Al}_{2} \mathrm{O}_{3}$ & 1 & 99.9 & 68.4 & 5.4 & 8.6 & 12.8 & 4.8 \\
\hline $\mathrm{Cu}-\mathrm{Co} / \mathrm{Al}_{2} \mathrm{O}_{3}$ & 2 & 98.4 & 56.6 & 16.2 & 10.4 & 12.2 & 4.6 \\
\hline $\mathrm{Cu}-\mathrm{Co} / \mathrm{Al}_{2} \mathrm{O}_{3}$ & 4 & 98.2 & 43.0 & 35.0 & 10.0 & 3.5 & 8.5 \\
\hline $\mathrm{Co} / \mathrm{Al}_{2} \mathrm{O}_{3}$ & - & 42.7 & 10.5 & 35.0 & 8.5 & 6.5 & 39.5 \\
\hline
\end{tabular}

* Loading ratio used in the synthesis.

Reaction conditions: $200^{\circ} \mathrm{C}, 3.0 \mathrm{MPa}, 8 \mathrm{~h}$, Catalyst $0.5 \mathrm{~g}$, HMF $2.5 \mathrm{mmol}$, THF $20 \mathrm{~mL}$.

HMF: 5-hydroxymethylfuran; DMF: 2,5-dimethylfuran; BHMF: 2,5-bis hydroxymethylfuran; 5-MF: 5-methylfurfural; 5-MFOL: 5-methylfurfuryl alcohol; Oth: FOL, MF and few of unknown. 
A high temperature is therefore important for $\mathrm{C}-\mathrm{O}$ and $\mathrm{O}-\mathrm{H}$ hydrogenolysis of the intermediates BHMF, 5-MF, and/or 5-MFOL. Further increases in temperature resulted in over-hydrogenolysis products and the yield of DMF dropped. This suggests that the conversion of HMF to DMF had reached a maximum at $220{ }^{\circ} \mathrm{C}$, and the effect of further increases in the reaction temperature was insignificant. A reaction temperature of $220^{\circ} \mathrm{C}$ was therefore used in subsequent experiments.

\subsubsection{Effects of $\mathrm{H}_{2}$ pressure}

In hydrogenation/hydrogenolysis reactions, the solubility of $\mathrm{H}_{2}$, as well as other parameters (temperature and time), is important. A high $\mathrm{H}_{2}$ pressure is needed to accelerate the hydrogenation of biobased molecules [22]. The optimum $\mathrm{H}_{2}$ pressure for selective hydrogenation of HMF to DMF was identified by performing reactions at $220{ }^{\circ} \mathrm{C}$ and various pressures in the range 10-40 bar (Fig. 10). The conversion and selectivity both increased with increasing pressure up to $30 \mathrm{bar}$, and reached $100 \%$ and $78 \%$, respectively. The HMF conversion did not change significantly with further increases in pressure. The conversion of HMF to DMF increased with increasing $\mathrm{H}_{2}$ pressure up to 3.0 MPa because of the increasing solubility of $\mathrm{H}_{2}$ in the reaction mixture. However, pressures above 3.0 MPa did not significantly change the HMF conversion because of the larger amount of chemisorbed hydrogen $\left(\mathrm{H}_{\mathrm{ads}}\right)$ on the catalyst, which became saturated. However, above 3.0 MPa, a slight decrease in DMF selectivity was observed. This can be attributed to further opening and hydrogenation of the furan ring. $\mathrm{A} \mathrm{H}_{2}$ pressure of 3.0 MPa was therefore chosen for subsequent experiments.

\subsubsection{Effects of time}

The effects of time on the HMF conversion and the selectivity for DMF were investigated over the range $2-10 \mathrm{~h}$ at $220{ }^{\circ} \mathrm{C}$ and $3.0 \mathrm{MPa}$. Fig. 11 shows that only $21 \%$ conversion of $\mathrm{HMF}$ and $5.6 \%$ selectivity for DMF were achieved in $2 \mathrm{~h}$. When the reaction time was prolonged from 2 to $8 \mathrm{~h}$, the conversion reached $100 \%$ and the selectivity increased to $78 \%$. The increased selectivity for DMF with time corresponds to conversion of increasing amounts of intermediates such as BHMF,

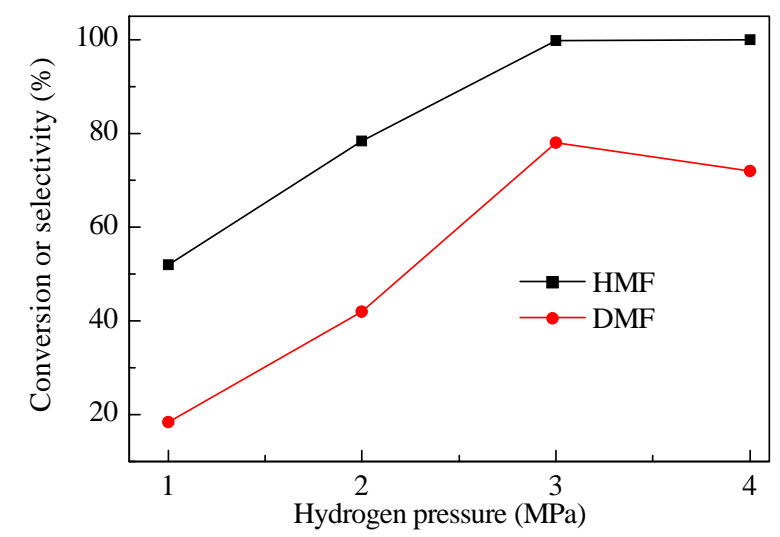

Fig. 10. Effect of hydrogen pressure on the conversion of HMF to DMF over $\mathrm{Cu}-\mathrm{Co} / \mathrm{Al}_{2} \mathrm{O}_{3}(\mathrm{Cu} / \mathrm{Co}=1)$. Reaction conditions: $220^{\circ} \mathrm{C}, 8 \mathrm{~h}$, Catalyst $0.5 \mathrm{~g}$, HMF $2.5 \mathrm{mmol}$, THF $20 \mathrm{~mL}$.

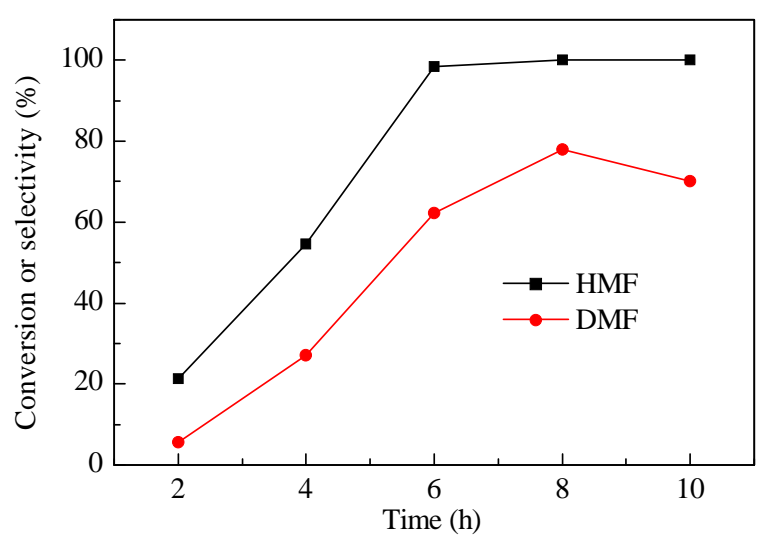

Fig. 11. Effect of time on the conversion of $\mathrm{HMF}$ to DMF over $\mathrm{Cu}-\mathrm{Co} / \mathrm{Al}_{2} \mathrm{O}_{3}(\mathrm{Cu} / \mathrm{Co}=1)$. Reaction conditions: $3.0 \mathrm{MPa}, 220^{\circ} \mathrm{C}$, Catalyst $0.5 \mathrm{~g}$, HMF $2.5 \mathrm{mmol}$, THF $20 \mathrm{~mL}$.

5-MF, and 5-MFOL to DMF. When the reaction time was further increased to $10 \mathrm{~h}$, the HMF conversion remained constant at $100 \%$; however, the selectivity for DMF decreased slightly. This can be attributed to the formation of increasing amounts of by-products when the reaction time increased beyond a certain value. A reaction time of $8 \mathrm{~h}$ was therefore used in subsequent experiments. The transformation of HMF to DMF proceeds via the intermediates BHMF or 5-MF, and then 5-MFOL. Conversion of both intermediates to DMF is considered to be slow and requires more time over $\mathrm{Cu}$-based catalysts.

\subsection{Stability of catalysts in HMF hydrogenolysis}

The $\mathrm{Cu}-\mathrm{Co} / \mathrm{Al}_{2} \mathrm{O}_{3}$ catalyst, which gave the best catalytic performance, was recycled twice to evaluate its stability. The HMF conversion and selectivity for DMF dropped from $100 \%$ to $62 \%$ and $78 \%$ to $42 \%$, respectively, in the second run (Table 5). The decrease in the catalytic activity was investigated by examining the differences between the structures of the spent and freshly reduced catalysts using TEM and CHNS analysis. TEM and CHNS analysis showed the presence of carbon after use. The TEM results showed that carbon was deposited on the active sites and the particle size increased after the second cycle; these factors could cause the significant drop in the activity of the catalyst. These observations agree with our previous work on FAL hydrogenation, in which coke formation was observed [29]. To confirm the reasons for the loss of catalytic activity, the

Table 5

Reusability of $\mathrm{Cu}-\mathrm{Co} / \mathrm{Al}_{2} \mathrm{O}_{3}(\mathrm{Cu} / \mathrm{Co}=1)$ catalyst toward hydrogenolysis of HMF to DMF.

\begin{tabular}{|c|c|c|}
\hline Catalysts & $\begin{array}{c}\text { Conversion of HMF } \\
(\%)\end{array}$ & $\begin{array}{c}\text { Selectivity of DMF } \\
(\%)\end{array}$ \\
\hline $\mathrm{Cu}-\mathrm{Co} / \mathrm{Al}_{2} \mathrm{O}_{3}$ (Fresh) & 100 & 78.0 \\
\hline a $\mathrm{Cu}-\mathrm{Co} / \mathrm{Al}_{2} \mathrm{O}_{3} 1^{\text {st }}$ cycle & 78.4 & 54.0 \\
\hline${ }^{\text {a }} \mathrm{Cu}-\mathrm{Co} / \mathrm{Al}_{2} \mathrm{O}_{3} 2^{\text {nd }}$ cycle & 62.4 & 42.6 \\
\hline${ }^{\mathrm{b}} \mathrm{Cu}-\mathrm{Co} / \mathrm{Al}_{2} \mathrm{O}_{3} 1^{\text {st }}$ cycle & 94.6 & 72.2 \\
\hline
\end{tabular}

a Without calcinations. ${ }^{\mathrm{b} W i t h}$ calcinations.

Reaction Conditions: $220^{\circ} \mathrm{C}, 3.0 \mathrm{MPa}$, Catalyst $0.5 \mathrm{~g}$, HMF $2.5 \mathrm{mmol}$, THF $20 \mathrm{~mL}, 8 \mathrm{~h}$. 
used catalyst ( $\mathrm{Cu}-\mathrm{Co} / \mathrm{Al}_{2} \mathrm{O}_{3}$ after the second cycle) was calcined at $500{ }^{\circ} \mathrm{C}$ and activated in situ at $280{ }^{\circ} \mathrm{C}$ to remove deposits, and then tested under same reaction conditions. As expected, the conversion of HMF and selectivity for DMF both increased, to $94 \%$ and $72 \%$, respectively. It can therefore be concluded that the catalyst lost activity because coke formed during HMF hydrogenation covered the active sites on the catalyst.

\section{Conclusions}

Three supported bimetallic catalysts, i.e. $\mathrm{Cu}-\mathrm{Co} / \mathrm{CeO}$, $\mathrm{Cu}-\mathrm{Co} / \mathrm{ZrO}_{2}$, and $\mathrm{Cu}-\mathrm{Co} / \mathrm{Al}_{2} \mathrm{O}_{3}$, with $\mathrm{Cu} / \mathrm{Co}$ molar ratios of 1,2 , and 4 were used in the hydrogenolysis of HMF to DMF. The intrinsic properties of the carriers and the strong interactions between $\mathrm{Cu}$ and $\mathrm{Co}$ significantly affected the catalytic performances of the $\mathrm{Cu}$-based bimetallic catalysts. The activity of $\mathrm{Cu}-\mathrm{Co} / \mathrm{CeO}_{2}$ in $\mathrm{C}-\mathrm{O}$ bond breakage was modest because of its large $\mathrm{Cu}$ particles and low acidity. $\mathrm{Cu}-\mathrm{Co} / \mathrm{Al}_{2} \mathrm{O}_{3}$ was much more active in hydrogenation/hydrogenolysis of HMF because of the presence of metallic $\mathrm{Cu}$ and mixed copper-cobalt oxides, and appropriate acidic sites. $\mathrm{Cu}-\mathrm{Co} / \mathrm{ZrO}_{2}$ showed similar activity but different product selectivity because of morphological differences and the presence of strong acidic sites. The catalytic activity of $\mathrm{Cu}-\mathrm{Co} / \mathrm{Al}_{2} \mathrm{O}_{3}$ in the conversion of $\mathrm{HMF}$ to DMF increased with increasing Co loading and the activities of the bimetallic catalysts were higher than those of their monometallic counterparts. The catalyst with the highest loading $(\mathrm{Co}=\mathrm{Cu}$ $=10 \mathrm{wt} \%$ ) gave an excellent catalytic performance; this is attributed to the presence of mixed copper-cobalt oxide species on porous $\mathrm{Al}_{2} \mathrm{O}_{3}$. Time and temperature were important parameters in the selective conversion of HMF to DMF. Based on these promising results, further studies will focus on the reaction mechanism and kinetics of HMF conversion.

\section{References}

[1] D. M. Alonso, S. G. Wettstein, J. A. Dumesic, Chem. Soc. Rev., 2012, 41, 8075-8098.

[2] S. Datta, S. De, B. Saha, I. Alam, Catal. Sci. Technol., 2012, 2, 2025-2036.

[3] K. Yan, A. C. Chen, Fuel, 2014, 115, 101-108.

[4] J. A. Melero, J. Iglesias, A. Garcia, Energy Environ. Sci., 2012, 5, 7393-7420.

[5] A. Corma, S. Iborra, A. Velty, Chem. Rev., 2007, 107, 2411-2502.

[6] X. H. Zhang, T. J. Wang, L. L. Ma, C. Z. Wu, Fuel, 2010, 2697-2702.

[7] M. Chatterjee, T. Ishizaka, H. Kqwqnami, Green Chem., 2014, 16, 1543-1551.

[8] T. Thananatthanachon, T. B. Rauchfuss, Angew. Chem. Int. Ed., 2010, 49, 6616-6618.

[9] Y. Roman-Leshkov, C. J. Barrett, Y. Z. Liu, J. A. Dumesic, Nature, 2007, 447, 982-985.

[10] T. B. Rauchfuss, T. Thananatthanachon, US 8324409 B2, 2012.

[11] T. A. Brandvold, US 8314267 B2, 2012.

[12] T. B. Rauchfuss, T. Thananatthanachon, US 2011/0263880 A1, 2011.

[13] M. Chidambaram, T. B. Alexis, Green Chem., 2010, 12, 1253-1262.

[14] S. Nishimura, N. Ikeda, K. Ebitani, Catal. Today, 2014, 232, 89-98.

[15] Y. H. Zu, P. P. Yang, J. J. Wang, X. H. Liu, J. W. Ren, G. Z. Lu, Y. Q. Wang, Appl. Catal. B, 2014, 146, 244-248.

[16] J. J. Shi, Y. Y. Wang, X. N. Yu, W. C. Du, Z. Y. Hou, Fuel, 2016, 163, 74-79.

[17] G. H. Wang, J. Hilgert, F. H. Richter, F. Wang, H. J. Bongard, B. Spliethoff, C. Weidenthaler, F. Schiith, Nat. Mater., 2014, 13, 293-300.

\section{Graphical Abstract}

Chin. J. Catal., 2017, 38: 699-709 doi: 10.1016/S1872-2067(17)62789-X

Influence of supports for selective production of 2,5-dimethylfuran via bimetallic copper-cobalt catalyzed 5-hydroxymethylfurfural hydrogenolysis

Sanjay Srivastava, G. C. Jadeja, Jigisha Parikh* Sardar Vallabhbhai National Institute of Technology, India

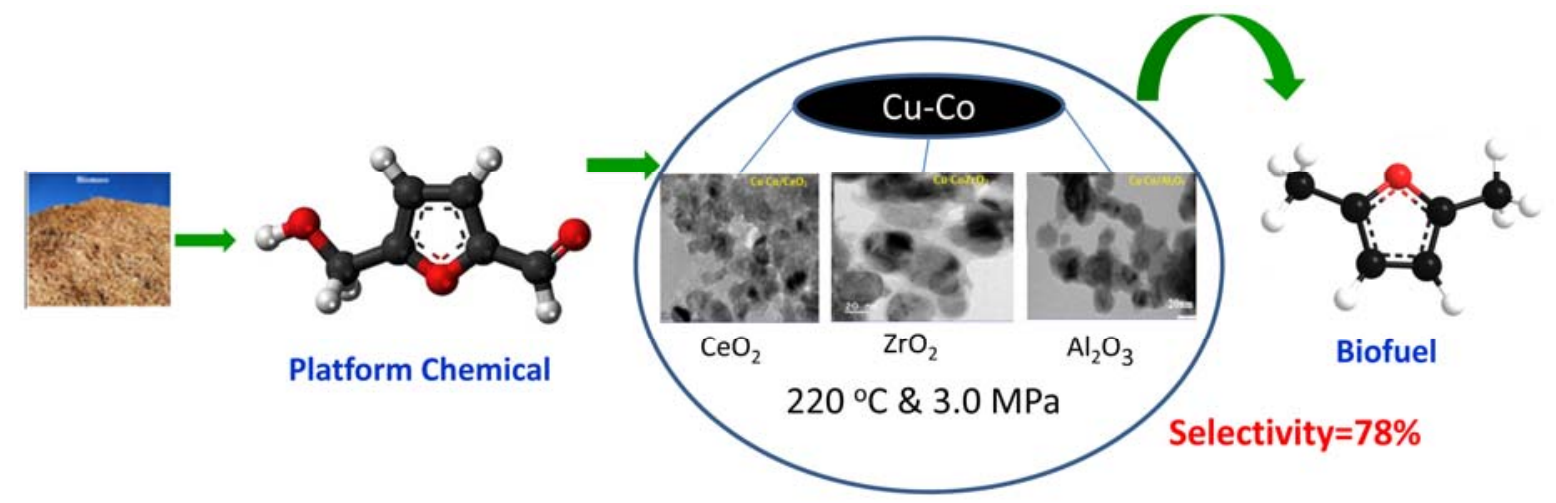

The present study explored the use of non-noble, environmentally benign, bimetallic copper-cobalt catalysts in the selective production of 2,5-dimethylfuran via 5-hydroxymethylfurfural hydrogenolysis. 
[18] J. B. Binder, R. T. Raines, J. Am. Chem. Soc., 2009, 131, 1979-1985.

[19] G. C. A. Luijkx, N. P. M. Huck, F. V. Rantwijk, L. Maat, H. Bekkum, Heterocycles, 2009, 77, 1037-1044.

[20] P. Yang, Q. Cui, Y. Zu, X. Liu, G. Lu, Y. Wang, Catal. Comm., 2015, 66, 55-59.

[21] Y. Zhu, X. Kong, H. Zheng, G. Ding, Y. Zhu, Y. W. Li, Catal. Sci. Tech., 2015, 5, 4208-4217.

[22] A. J. Kumalaputri, G. Bottari, G. J. Erne, H. J. Heeres, K. Barta, ChemSusChem, 2014, 7, 2266-2275.

[23] T. S. Hansen, K. Barta, P. T. Anastas, P. C. Ford, A. Riisager, Green Chem., 2012, 14, 2457-2461.

[24] Y. J. Fang, Y. Liu, L. H. Zhang, Appl. Catal., 2011, 397, 183-191.

[25] S. X. Yin, Q. F. Ge, Catal. Today, 2012, 194, 30-37.

[26] B. M. Reddy, G. K. Reddy, K. N. Rao, A. Khan, I. Ganesh, J. Mol. Catal. A, 2007, 265, 276-282.

[27] S. Srivastava, N. Solanki, P. Mohanty, K. A. Shah, J. K. Parikh, A. K. Dalai, Catal. Lett., 2015, 145, 816-823.

[28] S. Srivastava, P. Mohanty, J. K. Parikh, A. K. Dalai, S. S. Amritphale, A. K. Khare, Chin. J. Catal., 2015, 36, 933-942.

[29] S. Srivastava, G. C. Jadeja, J. K. Parikh, RSC Adv., 2016, 6, 1649-1658.

[30] G. R. Sheffer, R. A. Jacobson, T. S. King, J. Catal., 1989, 116, 95-107.

[31] M. Blanchard, H. Derule, P. Canesson, Catal. Lett., 1989, 2, 319-322.

[32] J. E. Baker, R. Burch, S. J. Hibble, P. K. Loader, Appl. Catal. A, 1990, 65, 281-292.

[33] J. E. Baker, R. Burch, S. E. Golinski, Appl. Catal. A, 1989, 53,
279-297.

[34] J. Wang, P. A. Chernavskii, A. Y. Khodakov, Y. Wang, J. Catal., 2012, 286, 51-61.

[35] S. Koso, I. Furikado, A. Shimao, T. Miyazawa, K. Kunimoria, K. Tomishige, Chem. Commun., 2009, 2035-2037.

[36] W. J. Xu, H. F. Wang, X. H. Liu, J. W. Ren, Y. Q. Wang, G. Z. Lu, Chem. Commun., 2011, 47, 3924-3926.

[37] W. Nabgan, A. T. AbdullahT, R. Mat, B. Nabgan, S. Triwahyonoc, S. Ripin, Appl. Catal. A, 2016, 527, 161-170.

[38] G. C. Bond, Platinum Metals Rev., 1983, 21, 16-18.

[39] Z. Wang, J. J. Spivey, Appl. Catal. A, 2015, 517, 75-81.

[40] M. Trueba, S. P. Trasatti, Eur. J. Inorg. Chem., 2005, 3393-3403.

[41] C. Morterra, G. Magnacca, Catal. Today, 1996, 27, 497-532.

[42] G. Paglia, C. E. Buckley, A. L. Rohl, R. D. Hart, K. Winter, A. J. Studer, B. A. Hunter, J. V. Hanna, Chem. Mater., 2004, 16, 220-236.

[43] G. Busca, Catal. Today, 1998, 41, 191-206.

[44] B. M. Nagaraja, A. H. Padmasri, P. Seetharamulu, K. H. P. Reddy, B. D. Raju, K. S. Rama Rao, J. Mol. Catal. A, 2007, 278, 29-37.

[45] A. Bienholz, H. Hofmann, P. Claus, Appl. Catal. A, 2011, 391, 153-157.

[46] S. Sitthisa, A Wei, D E Resasco, J. Catal., 2011, 284, 90-101.

[47] G. J. Kroes, Progr. Surf. Sci., 1999, 60, 1-85.

[48] A. Salin, J. Chem. Phys., 2006, 124, 104704/1-104704/9.

[49] W. M. Shaheen, A. A. Ali, Mater. Res. Bull., 2001, 36, 1703-1716.

[50] F. Diehl, A. Y. Khodakov, Oil Gas Sci. Technol., 2009, 64, 11-24.

[51] L. Bui, H. Luo, W. R. Gunther, Y. Roman-Leshkov, Angew. Chem. Int. Ed., 2013, 52, 8022-8025.

\title{
载体对其负载的Cu-Co双金属催化剂上5-羟甲基糠醛氢解选择性 生成2,5-二甲基呋喃的影响
}

\author{
Sanjay Srivastava, G. C. Jadeja, Jigisha Parikh * \\ 萨达尔瓦拉巴伊国立技术研究所化工系，苏拉特395007，古吉拉特邦，印度
}

摘要: 碳-氧键氢解是生物质呋喃基化合物制备交通燃料常见的模型反应, 其中5-羊基甲糠酫(HMF)转化为汽油添加剂2,5二甲基呋喃(DMF)尤为引人关注. 本文采用 $\mathrm{CeO}_{2}, \mathrm{ZrO}_{2}$ 和 $\mathrm{Al}_{2} \mathrm{O}_{3}$ 负载的 $\mathrm{Cu}-\mathrm{Co}$ 双金属催化剂用于 $\mathrm{HMF}$ 选择性氢解制DMF的 反应中. 采用 $\mathrm{X}$ 射线衍射、 $\mathrm{N}_{2}$ 吸附-脱附、投射电镜、 $\mathrm{H}_{2}$-程序升温还原、氨-程序升温脱附和元素分析表征了新鲜的和使用 过催化剂的结构, 并将其与催化活性相关联. $\mathrm{Cu}-\mathrm{Co} / \mathrm{CeO}_{2}$ 催化剂通过在大的 $\mathrm{Cu}$ 颗粒上还原 $\mathrm{C}=\mathrm{O}$ 键生成了最多的 2,5 双(羟甲 基呋喃) (BHMF). 但Cu-Co/ $\mathrm{Al}_{2} \mathrm{O}_{3}$ 催化剂具有高度分散的 $\mathrm{Cu}, \mathrm{Cu}-\mathrm{Co}$ 复合氧化物和大量的弱酸位, 因而生成DMF的选择性最 高. $\mathrm{Cu}-\mathrm{Co} / \mathrm{ZrO}_{2}$ 催化剂则由于存在强酸位, $\mathrm{DMF}$ 选择性较低, 生成了各种过度氢解产物, 如 2,5而甲基四氢呋喃和5,5-二(亚 甲基)双(2-甲基呋喃). 因此, 考察了 $\mathrm{Cu}-\mathrm{Co} / \mathrm{Al}_{2} \mathrm{O}_{3}$ 催化剂上的反应路径, 以及温度、氢气压力和时间等操作条件的影响, 使其 具有较优的HMF转化率和DMF选择性.

关键词: 5-羟甲基糠醛; 加氢; 氢解; 铜-钴; 双金属; 生物燃料

收稿日期: 2016-12-16. 接受日期: 2017-01-10. 出版日期: 2017-04-05.

*通讯联系人. 电话: +91-261-2251689; 电子信箱: jk_parikh@yahoo.co.in

本文的英文电子版由Elsevier出版社在ScienceDirect上出版(http://www.sciencedirect.com/science/journal/18722067). 